\title{
Bourdieu Sosyolojisi Bağlamında Bir Alt-Alan Olarak Yerel Basın: İzmir Örneği
}

\section{Gökçen Başaran İnce}

Doçent Dr. gokcenbasaran@gmail.com Ege Üniversitesi İletişim Fakültesi Orcid: 0000-0002-3114-001X

\section{Local-Press as a Sub-field in Context of Bourdieu's Sociology: Case of İzmir}

\begin{abstract}
This research aims to construe the features of local press in Turkey which can be categorised as a sub-field of journalism in terms of Pierre Bourdieu's sociology. The work analyses local press within the concepts of field, capital, habitus and strategy by semi-structured in-depth interviews with local press workers. Data from the research is analysed by theme analysis. Overall results indicate that the field of journalism is assesed as strongly heteronomous and social capital is deemed more important in terms of entrance to the field than cultural capital. Journalists also stress that terms of entrance to the field are quiet flexible and require less of cultural capital and good journalism entails habitus features such as extroversion, bravery and rashness. Main strategies in the field are comprised of exit and escape rather than subversion or protection.
\end{abstract}

Key Words: Pierre Bourdieu, field, capital, local press, Turkey 


\section{La presse locale comme un sous-champs dans le contexte de la sociologie de Bourdieu : le cas d'izmir}

\section{Résumé}

L'objectif de cette recherche est d'explorer les charactéristiques de la presse locale, qui peut être conceptualisé comme un sous-champs du journalisme en Turquie, à travers la théorie de Pierre Bourdieu. Dans cet article, l'expérience sur la presse locale est analysée à travers les concepts de champs, d'habitus et de stratégie de Bourdieu. Partant de cet objectif, des entretiens ont été menés avec des journalistes qui travaillent dans la presse locale et les résultats de la recherche ont été interprétés avec une analyse thématique. Ce qu'on peut obtenir de ces entretiens est qu'avec les faits politiques, surtout des dernières années, le domaine du journalisme en Turquie est devenu particulièrement hétéronome et que les conditions de pouvoir entrer dans ce domaine exigent un capital social plus qu'un capital culturel. En plus, les journalistes ont affirmé que le processus d'entrer dans le domaine est très variant et exige un capital culturel relativement bas et que le journalisme demande un habitus particulier qui comprend courage, sociabilité et esprit d'initiative. Les stratégies principales dans ce domaine sont ceux de sortir du jeu et d'y échapper au lieu de le protéger et détruire.

Le mots-clés: Pierre Bourdieu, champs, capital, presse locale, Turquie

\section{Öz}

Bu araştırmanın amacı, Pierre Bourdieu teorisi üzerinden Türkiye'de gazeteciliğin alt alanı olarak kavramsallaştırılabilecek yerel basının özelliklerini yorumlamaktır. Çalışmada, Bourdieu'nün alan, sermaye, habitus ve strateji kavramları ile yerel basın tecrübesi analiz edilmektedir. Bu amaçla yerel basında çalışan gazeteciler ile yarı-yapılandırılmış derinlemesine görüşmeler yapılmış, araştırma sonuçları tema analizi ile yorumlanmıştır. Görüşmelerin ortak kavrayışı, özellikle son yıllardaki politik gelişmelerle birlikte Türkiye'de gazetecilik alanının yüksek düzeyde heteronom hale geldiği ve alana giriş şartlarının kültürel sermayeden ziyade sosyal sermayeyi talep ettiğidir. Gazeteciler ayrıca, gazetecilik alanına girişlerin büyük oranda esneklik gösterdiğini ve kültürel sermayeyi görece az talep ettiğini ve gazeteciliğin, ataklık, girişkenlik, sosyallik vb. özellikler içeren kendine has bir habitusu gerektirdiğini belirtmişlerdir. Alanda sürdürülen temel stratejiler koruma ve yıkmadan çok, oyundan çıkma ve kaçış stratejileridir.

Anahtar sözcükler: Pierre Bourdieu, alan, sermaye, yerel basın, Türkiye 


\section{Giriş}

Neo-liberalizmin ekonomik ve politik yansımalarının '80'lerle birlikte Türkiye'ye nüfuz etmesi ve son yıllardaki politik dönüşümün, sektörde belirginleşen yoğunlaşma eğilimi ile birleşmesi, gazetecilik alanının otonomisini neredeyse tamamen bitirmiş durumdadır. Alan, makro düzeyde zayıf bir demokrasi geleneğinin, mikro düzeyde ise örgütlenme eksikliğinin sonuçları ile yüzleşmektedir. Yapısal sorunların tarihselliği bir yana, son yıllardaki hızlı ve kökten dönüşümler, var olan gelenekleri iyiden iyiye zayıflatmış ve heteronomiyi neredeyse olağanlaştırmıştır. Bu bağlamda alanın değişen özelliklerinin analizi önem kazanmıştır.

Bourdieu neolojisini, sosyolojinin ana düşünsel izleğini yeniden yorumlamak ve bu gelenekleri aşmak üzerine oluşturmuştur. Yapının bireyi öncelediği nesnelci gelenek ile, sosyal olanın bilgisinin fenomenolojik/öznelci bir inşa pratiğine, dolayısıyla özneler arası olana indirgendiği öznelci geleneği iki uç olarak yorumlayan Bourdieu; alan, habitus, sermaye ve strateji kavramlarını bu iki ucu birleştirme denemesi nedeniyle geliştirmiştir. Faili önceleyen yapılar (alanlar) vardır elbette, ancak bunlar değişmez ve mutlak değil, tarihsel ve dinamiktir. Failler sahip oldukları farklı sermaye türleri ve habitusları aracılığıyla, sürekli bir iktidar mücadelesinin var olduğu alanları dönüştürürler/"yeniden üretirler" ve kendileri de dönüşürler. Dolayısıyla sosyal olan, iç içe geçmiş, birbirinin otonomisine etki eden farklı alanlardan oluşur. Bu iç içe geçmiş ilişkiyi kuramsallaştırma tecrübesini Bourdieu, "inşacı yapısalcılık" ya da "yapısalcı inşacılık" olarak adlandııı (1989, s.20). Sosyal alan, bizden önce vardır, bizden sonra da var olacaktır; ancak sadece anlam değil, eylem de üreten fail olarak bireyler sahip oldukları farklı sermaye türleri ile temelde bir iktidar/mücadele unsuru olan alanda yerlerini alacak ve koruma/yıkma stratejileri ile yapının tarihselliğini sağlayacaklardır. Bu tarihselliği vaat eden en önemli unsurlardan biri ise, bireyin sosyal genetiğini oluşturan habitus olacaktır. Bourdieu'yu Marx, Weber ve Durkheim ile birleştiren düşünce çizgisi, sosyal olanın gücüne yaptığı vurgu yanında, onun iktidara içkin niteliğini sürekli vurgulamasıdır (Bourdieu, 1985). Bu iktidar alanının, ekonomiyle bağlantılı nitelikleri yanında, sosyal ve hatta simgesel özelliklerini vurgulaması, Bourdieu'nun Marx ve Weber'i birlikte okuma çabasını yansıtır. Dolayısıyla Bourdieu, çok katmanlı ve çok değişkenli bir "yapı" okuması denemektedir.

Bu araştırmada amaçlanan, Bourdieu kavramlarından -özellikle alan, sermaye ve strateji- Türkiye'de gazetecilik alanını (Durna, 2016) ve onun alt-alanı olarak kavramsallaştıılabilecek yerel basını anlamak için yararlanmaktır. Durna'ya göre 80'lerle birlikte endüstrileşmeye başlayan basın; Bourdieu'nun alanın oluşumu için öngördüğü özerkliğin kazanılması, karşıtılıkların/antagonizmaların yaratılması ve simgesel sermayenin oluşumu aşamalarını geçerek bir "alan" halini almıştır. Sonrasında ise "mesleğin yeniden tanımlanması" aşamasına gelinmiş ve özellikle Doğan Medya Grubu "köşe yazma, haber yapma, program sunma" vb. sembolik örüntülerden oluşan yeni bir gazeteci tipinin oluşturulmasında ana role soyunmuştur (Durna, 2016). 
Günümüzde sahiplik yapısı hayli tekelleşmiş, içeriği tektipleşmiş, otonomisi oldukça tartışmalı; ancak buna karşın bünyesinde hala karşıtıkları/antagonizmaları barındıran ve simgesel sermayesini sürdüren bir alan olarak basından söz etmek mümkündür. Yerel basın ise Basın Illan Kurumu'ndan ilan almaya dayalı bir memuriyet ve iş koluna indirgenmiş durumdadır. Büyük gazetelerin bölge ekleri, ana gazeteye sadece insan hikayelerini ya da polis-adliye haberlerini geçebilmekte ve yerel basının belediyelerden ve Basın İlan Kurumu'ndan ilan alma baskısı ile kısıtladığı içerik, bölgesiyle ilgili eleştirel haberler bulamayan okuru yerel basından uzaklaştırmaktadır. Okurun yerel gazete ilgisinin ilan verme/ilan takip etme boyutu da, internetin devreye girmesi ile birlikte azalmış ve gazete satışını düşürmüştür. Ulusal basının yaşadığı kriz, yerel basını tükenme noktasına getirmiştir. Bu bağlamda, yerel basından gazetecilerle görüşmeye dayalı bu araştırma, gazetecilik alanının geneli ile ilgili görüşler yanında, yerel basının temel özellikleri, alana giriş şartları, alanda sürdürülen stratejiler ve gazeteci habitusunu anlama amaçlı sorular içermektedir.

\section{Bourdieu Sosyolojisi'nin Temel Kavramları}

Pierre Bourdieu'yü 20.yüzyılın en önemli sosyologlarından biri yapan temel neden, sosyolojinin iki ana düşünce izleğinin temel sorunlarını tespit ederek, bu sorunların üstesinden gelmeye çalışması ve bu amaçla, ampirik araştırmadan ilhamla oluşturulmuş bir dizi kavram setini, literatüre maharetle eklemlemesidir. Batı düşüncesinde 20. yüzyılda fenomenoloji ve yapısal antropoloji bağlamında şekillenen tartışmalar, Bourdieu'yü Bachelard ve Canguilhem ve Claude Levi-Strauss'un görüşleri bağlamında etkilemiştir. Bachelard'ın gerçekliği bir "temsil" olarak gören fikirleri, Canguilhem'in "nihai bir gerçeklikten çok, sadece bu gerçekliği görmeye dair farklı yorumlar olduğunu" söyleyen görüşleri ve Kierkegaard, Husserl ve Heidegger'in bireysel tercih ve karar almayı "özgürlük" olarak kavramsallaştıran fenomenolojik ve varoluşçu yorumları ile; Levi-Strauss'un bireysel özgürlügü önceleyen ve davranışı belirleyen sosyal kurallar (kutsal-profan algısı ve kültürel tabu) olduğu fikrini (bkz. Grenfell, 2008), "alan, strateji, sermaye ve habitus" kavramları altında yeniden yorumlayan Bourdieu, subjektivist ve objektivist görüşler arasında bir denge arayışındadır. Bireyler ne tam özgür, ne de tam anlamıyla yapısal kuralların etkisiyle hareket ederler. Onlar kişisel kazanımlarını artırmak üzere, alanda karlarını hesaplayarak, stratejilerle eylerler ve bu pratikler "sosyal olarak şekillendirilmiş ancak bireysel olarak yapılandıııımış kişisel edimler" dir (Grenfell, 2008, s.44).

Bourdieu'ye göre sosyal olanın bilgisi, eylemden ve dış dünyanın bilgisinden bağımsız olmayan, ancak zihinde habitus ile tarihselleşmiş ve aktarılmış, dıştan içe olduğu kadar içten de dişa şekillenen bir sürecin sonucudur (bkz. Bourdieu, 2014 ve Jourdain\&Naulin, 2016). Dolayısıyla maddi dünyanın bilgisini, kendi özgül nitelikleriyle ve bedensel olanın bilgisiyle işleyen bir zihnin varlığı ile sosyal olanın ortaya çıkması mümkündür. Bourdieu, düşüncesinin bu izleği ile eylem halinde özneyi (fail), alanlar içindeki bağıntısal etkinliği ile (Bourdieu ve Wacquant, 2016, s.81) sosyolojiye döndürmenin yanında, Kartezyen düalizminin klasik önermelerini 
de tartışmaya açar. Bu önermelerin en bilineni zihin ve beden arasında yapılan ayrımdır. Bourdieu bu dualizm yanında fail-yapı, yapısalcılık-inşacılık, teori-ampirik bilgi arasındaki ikilikleri de aşmaya çabalar. Yukarıda sözü edildiği üzere, kendi teorisini "inşacı yapısalcılık" ya da "yapısalcı inşacııık" olarak adlandırmasının nedeni budur.

"Alan", Bourdieu'nün sözü edilen çabasının şemsiye kavramıdır ve Bourdieu'nün diğer tüm kavramları, alanlar içinde işlevsel hale gelir. Alanlar, sosyal dünyanın yapı taşlarıdır. Onların içinde birbirimizle ilişkiler geliştirir, anlam ve yapıları inşa ederiz. Alanlar değişken ve dinamiktir, tarihseldir. Temel işleyiş biçimleri iktidar ilişkilerinden ayrı düşünülemez. Jourdain ve Naulin'e göre:

Alanlar, Pierre Bourdieu tarafından, iş bölümünün artmasına bağlı olarak toplumsal dünyanın artan farklılaşma süreci sayesinde toplumsal hayatın çevrelerinin özerkleşmesi olarak tanımlanmaktadır. Bir toplumsal alanın özerkleşmesi, kendine has amacının tanımlanmasından geçer. Örneğin siyasi alanın hedefi iktidardır. Iktisadi alanınki zenginlik, sanatsal alanınki tanınırlıktır (2016, s.122).

Failler alana karşılaşma, rekabet ve çatışma ilkeleri bağlamında, bir oyuna dahil olur gibi dahil olurlar. Oyuncular oyunun temel kurallarına (doxa), kazanacaklarına ve kaybedeceklerine (oyuna yatııma ve oynamaya değeceğine inanma-illusio) (Bourdieu, 2015) belli bir inanç taşıdıkları için alanda eylemeye razı olurlar. Doxa, "sorgulanmayan, muhakkak addedilen ortak inançlara" gönderme yapar ve sembolik iktidarın kaynağıdır. Alan ve habitusla yakından bağlantılı, doğal görülen inanç ve düşünceleri kapsar (Deer, 2008). Bu bağlamda Bourdieu aslında doxa'ya negatif bir anlam da yükler. Sembolik bir iktidar biçimi olarak doxa, ona maruz kalanların; onu uygulayanların ve doxanın kendisinin meşruiyetini sorgulamaması sayesinde var olur (Deer, 2008, s.121-122). Stringer'a göre, Bourdieu'nun terminolojisinde kurallar, ya da doxa, alan içinde faillerin davranışlarını tanımlayan ve eylemlerini yöneten ve grup üyeleri tarafından paylaşılan varsayım setleridir (2018, s.1992). Gazetecilik bağlamında alanın doxa'sı, "kabul edilmiş kurumsal rolleri, epistemolojik çerçeveleri ve etik standartları", aynı zamanda "hakikate dayalı haber hikayeleri inşa etmenin metodları" üzerine paylaşılan anlayışları içerir (Vos and Craft'dan akt. Stringer, 2018, s.1992). Bu varsayımlar, çeşitli yetenek, uzmanlık ve bilgi olarak da tanımlanan, alanın kültürel sermayesini oluşturur (Benson ve Neveu'den akt. Stringer, 2018, s.1992). Kültürel sermaye gazeteciliğin meşruiyetinin birincil kaynağıdır ve Vos'un belirttiği gibi, gazeteciliğe nihai otonomi ve gücünü bu sermaye türü verir (akt. Stringer, 2018, s.1993).

Alanlar kimi zaman muhakkak addedilen (taken for granted) bir tarihselliğe ve kurumsallığa sahipken, kimi zamansa şekil değiştirip başkalaşabilirler, yok olabilirler. Alanların temel özelliklerinden bir diğeri, sosyal alandaki bağıntısallığın temeli olmaları ve farkı mantıklarla işlemeleridir. Bourdieu bu durumu şöyle anlatır:

Toplumsal dünyada varolan şey, bağıntılardır; eyleyiciler arasındaki özlerarası bağlar ya da etkileşimler değil, Marx'ın dediği gibi “bireysel 
iradelerden ve bilinçlerden bağımsı" varolan nesnel bağıntılar. Çözümleyici açıdan alan, konumlar arasındaki nesnel bağıntıların konfigürasyonu ya da ağı olarak tanımlanabilir. Bu konumlar, varoluşları ve kendilerini işgal edenlere, eyleyicilere ya da kurumlara dayattıkları belirlenimler açısından farklı iktidar (ya da sermaye) türlerinin dağılım yapısındaki mevcut ve potansiyel durumlarıyla (situs), ayrıca diğer konumlara nesnel bağıntılarıyla (tahakküm, itaat, benzeşme vb.) nesnel olarak tanımlanır. Söz konusu iktidar (ya da sermaye) türlerine sahip olmak, alanda elde edilebilecek özgül faydalara erişimi belirler. Yüksek derecede farklılaşmış toplumlarda, toplumsal kozmos, diğer alanları düzenleyen mantık ve zorunluluklara indirgenemeyecek mantık ve zorunluluğun yeri olan görece bağımsız mikrokozmosların bütünüdür. Örneğin sanat alanı, din alanı ya da iktisadi alan, farklı mantıklara tabidir: iktisadi alan, tarihsel olarak, "işin iş olduğu" (business is business) ve duygusal akrabalık, arkadaşlık ve sevgi ilişkilerinin ilke olarak dışlandığı evren şeklinde ortaya çıkmıştı; sanat alanıysa tersine, maddi kar yasasının reddiyle ya da tersine çevrilmesiyle kurulmuştur (Bourdieu ve Wacquant, 2016, s.81).

Bourdieu burada temelde üç şeye işaret etmektedir: alanlar, faili ve failler arası ilişkileri önceler; gereksindikleri farklı iktidar ya da sermaye yapıları nedeniyle birbirinden farkıı işleyişlere ve yapılara sahiptir ve failler farklı sermaye türleri ile alanda farklı faydalara erişim sağlarlar. Dolayısıyla alanlar aynı zamanda çatışma ve rekabetin etkisine açılır. "Alan, -sadece anlam ilişkilerinin değil- güç ilişkilerinin ve bu ilişkileri değiştirmeyi hedefleyen mücadelelerin yeridir; dolayısıyla, sürekli değişim yeridir" (Bourdieu ve Wacquant, 2016, s.89). Alanlar açısından belirleyici olan bir diğer nitelik, Bourdieu'nün fenomenolojik/inşacı ve yapısalcı yaklaşımların kavrayışlarının ötesine geçme çabasıdır. Buna göre sosyal alan ne gerçekçi yaklaşımların önerdiği gibi sadece öznelerarası doğrudan etkileşim ve ilişkilere indirgenebilir, ne de yapısalcı yaklaşımların faili devre dışı bırakan hakim yapı anlayışına. Bourdieu'ye göre alandaki yapısal-nesnel ilişkiler ağı, öznelerarası görünür ilişkilerin ve etkileşimlerin şeklini ve içeriğini belirler (Kaya, 2016, s.397). Aynı zamanda, alanlara ait genel yasalardan söz etmek mümkündür. Siyaset alanı, felsefe alanı, din alanı gibi birbirinden son derece farkı alanlar birtakım değişmez işleyiş yasalarına tabidir (Bourdieu, 2016, s. 137).

Alanda çatışma ve rekabeti olası kılan temel nitelik, faillerin farklı sermaye türlerine sahip olmasıdır. Bourdieu'de "sermaye" kavramı, Marx'ın ekonomik sermaye kavramsallaştırmasını Weber ile buluşturarak, ekonomik olana sosyal, kültürel ve simgesel bir boyut ekler. Bourdieu böylece, sınıfsal ilişkilerin ötesinde ve onlarla birlikte işleyen çok boyutlu bir iktidar analizi yakalamış olur. Failler alan içinde sadece ekonomik değil, sahip oldukları farklı sermaye türleri ile de rekabet ederler. Ekonomik sermaye dışında, kültürel ve sosyal sermaye bunların başında gelir ve sembolik sermayenin sağladığı tanıma ile diğer sermaye tiplerinin meşruiyeti ve devamlılığı sağlanır. 
Bourdieu'ye göre ekonomik sermaye doğrudan ve anında paraya çevrilebilir olan sermaye türüdür ve mülkiyet hakları bağlamında kurumsallaşır. Kültürel sermaye ise kimi koşullarda ekonomik sermayeye dönüşebilir ve eğitimsel vasıflar olarak kurumsallaşır. Sosyal sermaye, sosyal zorunluluklardan ("bağlantılar") oluşur ve kimi durumlarda ekonomik sermayaye dönüşebilir, bir soyluluk ya da asalet ünvanı altında kurumsallaşmış olabilir (Bourdieu, 1986, s.242). Kültürel sermaye üç biçimde var olur: zihin ve bedenin uzun süreli karakterleri (dispositions) olarak cisimleşmiş/bedenselleşmiş biçimde (embodied state); kültürel ürünler (resimler, kitaplar, sözlükler, araçlar, makineler vb.) halinde nesneleşmiş biçimde (objectified state) ve kurumsallaşmış biçimde (institutionalized state). Kültürel sermayenin kurumsallaşmış biçimini ayrı tutmak gerekir çünkü kültürel sermayeye tamamen orijinal nitelikler verir (Bourdieu, 1986, s.243).

Sosyal sermaye, karşııklı tanıma ve tanıdıkığa dayalı az ya da çok kurumsallaşmış ilişkiler ağına sahip olmayla bağlantılı güncel ve potansiyel kaynakların toplamıdır ya da başka bir deyişle, her bir üyesine kolektif olarak sahip olunan bir sermayenin desteğini sağlayan, kelimenin bir çok anlamıyla üyelerine "kredi" sağlayan bir gruba üye olmaya denir (Bourdieu, 1986, s. 244). Kültürel, ekonomik ve sosyal sermayenin bir bütün olarak tanınması ve meşruiyetinin kabul edilmesi ile simgesel sermaye oluşur. Bourdieu simgesel sermayeyi şöyle tanımlar:

Simgesel sermaye -ayrım'ın (distinction y.n) diğer adıdır- farklı sermaye türlerinin bilinmesi ve tanınması durumunda, sermayenin dağıtımının yapısına dair içselleştirme (bedenselleşme)den doğan ve algı kategorilerine sahip herhangi bir özne tarafından herhangi bir biçimde algılanan herhangi bir sermaye türünden ayrı bir şey değildir. Filli (de facto y.n) farklılıkların sembolik ayrımlarının şekil değiştirmiş hali olarak ayrımlar ve daha genel olarak, rütbeler, nişanlar, payeler ve diğer tüm sembolik hiyerarşiler bu yapı tarzlarının uygulanmasının ürünüdür. En sosyal yargıların ifadesi olarak kullanılan sıfatlar, uyarlandıkları yapıların içselleştirilmesinin ürünüdür ve meşruiyetin en kati tanınması, nesnel yapılar ve bedenselleşmiş yapıların sözdemükemmel çakışmasından kaynaklanan gündelik hayatın aşikar kavrayışlarından başka bir şey değildir (1985, s. 204).

Bu tanıma göre simgesel sermaye, diğer sermaye türlerinin tanınması ve meşruiyetinin sağladığı, nihai bir sermaye bahşeder faillere. Alanlarda varlık gösteren faillerin, alanın gereksinimine göre edindikleri farklı sermayelerinin ötesine geçerek, sosyal ve sınıfsal farkların cisimleştiği, ayrımların keskinleştiği ve bu durumun içselleştirilerek, muhakkak addedildiği hiyerarşileri onama imkanı sağlar. Simgesel sermaye, ayrımların meşruiyetini, görünürlüğünü doğallaştıır ve yeniden üretir.

Bourdieu, alanların işleyişinde sermayenin öneminini sürekli vurgular. Çünkü alanların işleyişi, farklı sermaye türlerinin çatışması ve mücadelesinin sonucudur. Ayrım, alanlardaki sermaye tiplerinin değişen hiyerarşisinden doğar. Mücadele stratejileri, alandaki faillerin sermayelerini kullanma biçimlerini gösterir. Çatışma ve 
ittifaklar, faillerin birbirlerinin sermayesini tanıması ya da reddiyle ilişkilidir. Bourdieu, alanda iki temel strateji türü tanımlar: muhafaza stratejileri ve yıkım stratejileri (Jourdain ve Naulin, 2016, s.126). Alanın halihazırdaki sahipleri, oyunun kurallarına hakim olmayı sürdürmeyi, alanın sürekli yeniden üretimini ve dolayısıyla statükonun devamını savunurken; alana yeni girenler, alana dair sahip oldukları sermayenin işlevsizliğini gördükçe, alanın temel işleyişini değiştirmek isterler. "Bu kimseler, sermayelerinin yeniden değerlendirilmesi ve dolayısıyla konumlarının iyileştirilmesi amacıyla oyunun kurallarını ve hatta tümünü değiştirmeye uğraşarak, alandaki konumlar hiyerarşisinin geçerliliğini sorguladıkları için heretik tabir edilmektedirler" (Jourdain ve Naulin, 2016, s.127). Dolayısıyla alanların tümünde, ortodoksiyi savunan "eskiler" ve kuralları ve işleyişi kendi leyhlerine yeniden tanzim etmek isteyen "heretikler"/"yeniler" mevcuttur. Bu çatışma, alanı "yapı"dan farkııştıır ve Bourdieu'nun "inşacı yapısalcılık" görüşünü anımsatır.

Bourdieu'ye göre her alanın işleyiş mantığı kendine özgüdür ve alanlar kendilerini farklı mücadele nesneleri üzerinden tarif eder. "Bu mücadele nesneleri tür ve içerik bakımından diğer alanlar için geçerli olan mücadele nesnelerine indirgenemez, bunlarla aynı değildir" (2016, s.138). Dolayısıyla bir alanda uğruna mücadele edilen değerler, başka bir alanda geçersiz, garip, hatta komik bulunabilir. Örneğin sanat alanının ekonomik sermayeyle kurduğu ilişki-Bourdieu buna tersine ekonomik dünya der- ekonomi alanının anlam veremeyeceği bir tercihtir. Sanatçılar zenginleşmek ya da popüler olmak değil, sanat alanının eksperleri tarafından kabul görmek isterler. Bu ekonomik sermayeden çok, kültürel ve simgesel sermayeye duyulan ilgiyi gösterir.

Bourdieu'ye göre "herhangi bir alanın işleyebilmesi için, söz konusu alana has belirli birtakım mücadele nesnelerinin varlığı ile oyunun ve mücadele nesnelerinin doğasına ilişkin içkin kuralları bilen ve ikrar eden habituslarla donanmış, oyuna katımaya ziyadesiyle hevesli faillerin varlığı gereklidir" (2016, s.138). Bu bizi Bourdieu'nün bir diğer önemli kavramına götürür: Habitus. Habitus, bireylerin bilinçli olarak etkilerinden haberdar olmadıkları, ancak onların zihinsel etkinliklerini düzenleyen süreğen, aktarılabilir eğilimler (dispositions) seti olarak anlaşılabilir (Bourdieu, 1977, s.72). Bourdieu, habitusu sosyal faillerin (birey, grup ya da kurum farketmeksizin), "yapılandırılmış ve yapılandıran bir yapı" (a structured and structuring structure) (1994, s.170'den akt. Maton, 2008, s.51) oluşturan niteliği olarak tanımlar. Habitus, failin geçmiş ve geleceğinin koşulları -örneğin aile yapısı ve yetiştirilme tarzı, eğitim vs- aracılığıyla "yapılandııımıştır" (structured). Ancak failin habitusu, onun şimdiki ve gelecekteki pratiklerini şekillendirmeye yardım eder, bu bağlamıyla "yapılandııcıdır" (structuring). Habitus kendisi bir "yapıdır" (structure) çünkü gelişigüzel ve rastlantısal olmaktan çok sistematik olarak düzenlenmiştir. Bu "yapı" algı, pratik ve değerlendirmeler üreten bir yatkınlıklar sistemi oluşturur (Bourdieu 1990, s.53'ten akt. Maton, 2008, s. 52). Suminar'a göre habitus, nesnel yapı ve öznel algılamanın insan eylemini etkileme biçimini açıklamak için kullanılır. Kavram, düşünce ve eylemin öncül deneyimlerinin ürünü olan düzenleyici şema setleri olarak açıklanabilir (2013, s.202). Bu düzenleyici şemalarda, "Belirsizlik ve muğlaklık el ele ilerler. Sürekli-yenilenen durumlarla, doğaçlama 
yüzleşmelerle kendini öne süren üretken bir spontanlığa sahiptir. Kişinin dünyayla sıradan ilişkisini tarif eden, ortalamanın ve belirsizliğin pratik mantığına itaat eden bir spontanlıktır bu" (Bourdieu, 1990, s.77-78). Habitus, temelde, tamamen yapılandırımış değildir ve bu nedenle tarihsel, sosyal ve kültürel bağlamlardan etkilenmeyi kuvvetli biçimde sürdürür (Suminar, 2013, s.202). Habitus kavramı da en az alan kadar sosyolojinin alışılageldik kavram çiftlerini kırmak üzere geliştirilmiştir. Batı düşüncesinin klasikleşmiş düalizmlerinden olan zihin-beden ayrımı, habitus kavramı ile aşılmaya çalışıır. Habitus, kelimenin de çağrıştırdığı üzere (habit: alışkanlık y.n.), alışkanlık gibi tekrarlar sonucunda edindiğimiz, sadece zihnimizle değil bedenimizle de tanıdığımız bir şeydir (Calhoun, 2016, s.79). Eylemlerimizin önemli bir bölümü, üzerinde her gün yeniden düşünülmeyen ancak "disiplinli tekrarlarla öğrendiğimiz pratik etkinlikler"e (a.g.e, s.94) dayanır. Calhoun'a göre bu pratikler ancak alışkanlıklara dönüşürse çok iyi yapılabilir (örneğin düğme dikme). "Aynısı Bourdieu'ye göre, sadece fiziksel işler için değil, evleneceği eşi seçme veya armağan verme gibi çok daha karmaşık toplumsal ilişkiler için de söz konusudur" (a.g.e, s.94). İşte insan eylemlerindeki bu sürekliliği habitus sağlar. Aile ve toplum içinde edinilen yargllar, onaylanan/ayıplanan değerler, sosyal alanın inşasında muhakkak addedilen doxalar habitusa malzeme taşır. Habitus, sadece zihinsel olarak değil, bedensel olarak da bireyi sosyal gerçekliğe bağlar; eylem ve sezgiyi aynı anda barındıır:

"Habitus, bir anlamda bireyin karakteristik eylem eğilimleri seti olarak ortaya çıkar. Bu eğilimleri toplumsal düzen içindeki konumlara uygun kılan bir sosyal süreç vardır (başka bir ifadeyle, kişi statülerine uygun roller oynamayı öğrenir). Ancak habitus bundan daha fazlasıdır; kurumlar ve bedenler arasındaki buluşma noktasıdır. Yani o, biyolojik bir varlık olarak her bireyi sosyo-kültürel düzene -faklı hayat oyunları anlamlarını koruyacak, oyunu sürdürebilecek biçimlerde- bağlayan temel formdur" (Calhoun, 2016, s.104).

\section{Araştırma Sonuçları}

Bourdieu sosyolojisi izleğinde, İzmir'de gazetecilik alt-alanının özelliklerini anlamak üzere, görüşme yapılan gazetecilere alanın özellikleri, alana giriş şartları, alanda geçerli sermaye türleri, gazeteci habitusları ve alanda sürdürülen stratejiler üzerine sorular sorulmuştur. Bu amaçla Yeni Asır (2), Habertürk Ege (4), Dünya (1), Hürriyet Ege (1), Dokuz Eylül (1), Ege Telgraf (1), Ticaret (1) gazetelerinden toplam 11 gazeteci ile yarı-yapılandırılmış derinlemesine görüşmeler gerçekleştirilmiştir. ${ }^{1}$ Görüşme yapılan gazeteciler; 2 haber müdürü, 1 gazete sahibi/yazı işleri müdürü, 1 istihbarat şefi ve 7 muhabirden oluşmaktadır. Katılımcıların isteği ile kimlikleri ve çalıştıkları kurumlar gizli tutulacaktır. Araştırma verileri tema analizi tekniği ile yorumlanmıştır.

1 Yerel basın tanım olarak, belli bir bölgede basılıp, dağııımı sadece orada yapılan içeriği anlatmaktadır. Ancak bu araştırmada, "yerel basın", ulusal gazetelerin bölge eklerini de içine alacak biçimde yorumlanmışıı. Artık ulusal yayın yapan Yeni Asır ise, gazeteciler için hala yerel bir gazete olarak algılanmaktadır ve belleklerindeki yerini bu biçimiyle korumaktadır. Çalışanların çoğu bölge gazetesi olarak yayın yaptığı dönemin çalışanlarıdır. Bu nedenle Yeni Asır da araştırmaya dahil edilmiştir. 


\section{Alanın Özellikleri ve Stratejiler}

Bourdieu'ye göre, her alt-alanın kendi mantığı, kuralları ve özgün düzenlilikleri vardır (Bourdieu ve Wacquant, 2016, s.89). Bu bağlamda görüşme yapılan gazetecilere ana alanla bağlantılı ancak ondan bağımsız olarak, yerelde gazetecilik alanının temel özellikleri soruldu. Görüşme yapılan gazetecilere göre bir alt-alan olarak yerel basın, yüksek düzeyde heteronom (dıştan müdahaleye açık, otonom olmayan) bir nitelik göstermektedir. Heteronominin ana nedeni politik atmosferle birlikte -hatta ondan daha etkili biçimde- yerel basın üzerindeki ilan baskısı ve gazetelerin sahiplik yapısı gibi ekonomik nedenlerdir. Bu bulgu, Bourdieu'nün "kültürel alandaki tüm alt alanların, ekonomi alanı tarafından domine edildiği" (Bourdieu, 1990) fikri ile uyumludur. Gazetecilere göre, alanın ikincil niteliği, liyakat sisteminin zayıflığıdır. Alan, sınıfsal farkların çok derin gözlemlendiği, muhabirlerin en altta, bölge temsilcilerinin ise en üstte konumlandığı, ödül-ceza ve liyakat sistemi zayıf, katı bir "kast sistemi" olarak nitelenmektedir. Alanın bir diğer özelliği, özellikle 2000'li yılların ortalarından sonra giderek küçülmesidir. Muhabir sayısı radikal biçimde azalmış, gazeteler hızla daralmıştır. Muhabir eksikliği nedeniyle gazetelerin ajans haberlerine ve ambalaj haberlere bağımlılığı artmıştır. Gazeteciler, eskiye göre etkisiz ve simgesel sermayesi yiten bir meslek tasvir etmektedirler. Görüşme yapılan gazeteciler, İzmir'de gazetecilik pratiklerini ve gazetecilik alanını yorumlarken, yaşı ve mesleki tecrübesi yeterli olanların hissettikleri en temel duygu, mesleğin görece saygın ve yapılabilir olduğu eski günlere duyulan nostaljidir.

Alanın otonomi eksikliği gazetecilerin hepsinin hemfikir olduğu bir özelliktir. Çoğu, bu eksikliği politik alandan gelen baskılara ve gazetelerin sahiplik yapısı ve yerel basının yaşadığı ekonomik sorunlara bağlamaktadır. Alanın otonomisinin politik müdahaleler nedeniyle azaldığını düşünenlere göre, bu müdahaleler, yıllar içinde gittikçe dozu artan bir seyir izlemiş, dışsal müdahale bir süre sonra güçlü bir oto-kontrole dönüşmüştür:

(...)Müdahaleler şeyle başladı... Bilmem ne ilçe kongresinde bir partinin, A partisinin ilçe kongresinde kavga çıkmış, gırtlak gırtlağa sarılmış. "E bunu kullanmayın lütfen" ile falan başladı. Bu "lütfenler" daha sonra artmaya başladı. Şimdi nasıl olduya gelirsek, şimdi oto-kontrol o kadar fazla ki, artık bir muhabir görse bir hikâyeyi, "Nasılsa bizde çıkmaz" deyip (gülüyor y.n.) yapmıyor bile (...)Yani biz şunu yaşadık: Çıkmamış bir sağlık haberinin, eleştirel bir sağlık haberi nedeniyle bu haberi yapan, sayfaya koyan grafikeri, bilmem nesi, 4 kişiyi işten çıkardılar. Şimdi böyle bir süreçlerden geçerseniz, otomatikman oto-kontrol, o şey artıyor... (İstihbarat Şefi, 19 Ekim 2017)

Dışarıdan müdahale derken... şöyle..politik baskılar kesinlikle oluyor. Özellikle seçim dönemlerinde. Şimdi biz rahat bir dönemdeyiz yani ortada seçim vs. yok (...) Zaten müdahaleye de gerek yok. Bir şekilde kendi kendini kontrol ediyorsun. Ciddi bir oto-kontrol var. Bu haberi 
yaparsam işte şu olabilir falan diye düşünüyorsun...

GBi: Hep böyle miydi peki?

Hep böyle değildi tabii! Hep böyle değildi. Yani son 10 yıldır, 10 bile fazla... Son 5 yıldır artık iyice zıvanadan çıktı (Haber Müdürü, 19 Ekim 2017).

Politik baskı var. Nasıl var? Illa böyle boğazına yapışıp da şey değil..hani dedim ya, herkesin bir tarafı vardır. Bu da sonuçta şu an hükümeti destekleyen bir gazete. Tamam, yanlışları varsa, illa hükümeti destekliyoruz diye diğer ana muhalefetin işte belediyeleri hakkında kötü bir haber yapacağız diye bir zorunluluk yok yani. Adam diyor ki işte mesela tramvay bozulmuş. Git diyor. Ne oluyor? CHP'li Büyükşehir Belediyesi'nin hizmete soktuğu tramvay işte 3 günde bozuldu, mesela..o haber geniş geniş giriyor.. Onlara geçirme haberleri diyeyim, siz o tabirleri şey yaparsınız (gülüşme y.n.). Dediğim gibi politik anlamda baskı değil de, hani bir seçicilik gibi mi diyeyim, nasıl tanımlanır.. Mesela CHP'nin burada yaptığı çok güzel bir etkinlik oluyor, ben gidiyorum onu atıyorum 3000-5000 vuruş yazıyorum, gazetede tabii o editör baktığı zaman bir anda 3000 vuruşluk haber, 250 vuruşa düşebiliyor. Ama öteki ana muhalefetin şeyin, hükümetin, Ak Parti bir şey yapıyor bazan, ona 200 vuruş yazıyorsun, "Bu ne" diyor, "Biraz geniş yaz" diyor, "Geniş girecek bu haber" diyor (Muhabir, 16 Mayıs 2017).

Gazetecilerin oto-sansür olarak yaşadığı şey böylece, ideolojileri ya da işte tutunabilmek için gerekli gördükleri bir "taraf tutma" hali, oyunun kuralı biçimini alır. Burada Bourdieu'nün oyuna dair "kural" (rule) ve "düzenlilik" (regularity) kavramlarına dikkat çekmek gerekir. Bourdieu'ye göre sosyal oyun düzenlenmiştir (regulated) ve kimi düzenliliklerin mahalidir (akt. Maton, 2008). Failin pratiğini anlamak için, sosyal faillerin pratik mantığı ile sosyal alanların düzenlilikleri arasında bağ kurmak gerekir; faillerin "oyuna dair hissiyatı" (feel for the game), aslında bu düzenliliklere dair hissiyattır. Bu pratik mantığın kaynağı da habitus'tur (Maton, 2008, s.54). Dolayısıyla alanda oyunun kuralı, şu "his" ve "düzenlilik" ile işlemektedir: Gazetecilere doğrudan emirler, istekler iletilmemekte (baskı bir "kural"a dönüştürülmemekte), onlar çalıştıkları gazetenin isteklerini, beklentilerini içselleştirmekte, ona göre tavır almaktadırlar (baskı "düzenlilik"e, oto-sansür "pratiğe", koruma ise "strateji"ye dönüştürülmektedir). Haberin görülme biçimi, yeri, uzunluğu, dili bu noktada devreye girmekte, üstler astlara sistemin işleyişini öğretmektedirler.

Gazetecilik alanının otonomisine dair anlatılanlarda bir diğer ilgi çekici yan, otonomi sorununun sanıldığının aksine sadece doğrudan siyasal iktidarla değil, muhalefet vb. farketmeksizin "nüfuz" sahibi olanların, alan üzerinde kurdukları baskı ile ilintili görülmesidir: 
Herkesin çok sevdiği bir Belediye Başkanı ... işte solcu vs. böyle şey... ve gazete patronlarıyla, gazete yöneticileriyle ilişkileri çok kuvvetli. Mesela bu kişi bize bir arkadaşımızın yaptığı bir haber nedeniyle işten artırıdı. İşten atılmasına neden oldu yani! Ve sonra tabii o kadar ciddi şey geldi ki, baskı geldi ki, kendi işe almak zorunda kaldı. Tabii kısa sürede işte çalıştı arkadaş, sonra başka yere geçti ( Haber Müdürü, 19 Ekim 2017).

Fatih Terim'in bu Alaçatı' da bir sorun, sıkıntısı olmuştu, hatırlıyorsunuz. Habere biz ilkten ulaştık. Hiç, daha henüz hiçbir yerde yok yani. Bizimkiler sanıyor ki biz patlatacağız haberi ertesi gün manşet falan. Haber yazıldı. Kimin imzasını atalım? Senin atalım? Ben, yok. Senin atalım? Ben istemem. Çünkü uğraşılacak bir karakter değil Fatih Terim ve herkes bunun bilincinde ve korkuyor (...) İşte bu korku da oto-sansür sağlar diye düşünüyorum (Muhabir, 18 Ekim 2017).

Yerel gazetelerin otonomi eksikliği ve gazeteciler üzerindeki baskının önemli nedenlerinden biri de gazetelerin sahiplik yapısı olarak yorumlanmaktadır. Görüşme yapılan gazetecilere göre, gazete patronları haber içeriğine doğrudan müdahale ederek, ilgili yerlerden baskı gelmesine gerek bırakmadan, sistemi haber aleyhine işletmektedir. Bu kimi zaman doğrudan kendi çıkarlarını korumak, kimi zamansa otoritelerle ilişkileri tehlikeye atmamak için yapılmaktadır:

(...) Yaa iş adamları, patron olduğu sürece bu olmaz tabii. Yani iş adamı gazeteci olamaz, olmamalıdır bence. Mesela ben bugün 2 tane 3 tane haber gördüm. İşte maden eylemi mi ne? Kaydetmedim bile bak! Neden? Benim patronumun madeni mi? Muhtemelen değildir ama ... o alanla ilgili hiçbir şey görmüyorsun... Bunu bana biri söyledi mi? Hayır söylemedi. 2-3 kişi işten çıkarıldıktan sonra ben kendi kendime böyle bir vurgulamaya başladım (...) Çok soda içmek tansiyonu yükseltiyor diye, şu kadar çıkmış bir haber. Şimdi ne alaka değil mi yani? (Gülüyor) Bizim patronumuz soda şişesi üretiyormuş. Soda şişeleri de tabii soda üretenlere satılıyor. Hani böyle bir şey soda üreticilerine zarar verir, dolayısıyla bizim patronun işlerine zarar verir falan gibilerinden... Hükümet baskısını da patron kuruyor zaten sana (...) Her türlü baskı patrondan geliyor zaten. Ama birisi siyasal kaynaklı oluyor birisi iş kaynakı (İstihbarat Şefi, 19 Ekim 2017).

Otonomi eksikliğine neden olan politik ve ekonomik baskılar yanında gazetecilik alt-alanına dair yapılan önemli tespitlerden bir diğeri, alandaki gözle görülür gelir adaletsizlikleri, liyakat sistemindeki zayıflıklar ve ödül/ceza sisteminin işlememesidir. Bu sistem içinde en ağır yükü taşıyan muhabirler, mesleğin ekonomik ve simgesel sermayesi en zayıf grubunu oluşturmaktadır. Halihazırda muhabir olanlar, bir an önce muhabir olmaktan kurtulmayı istemekte, ancak sistem içindeki sosyal sermaye etkisi nedeniyle, terfinin güç olduğunu düşünmektedirler. 
Muhabirlere göre alanda oyunun kuralları, birbirini kayıran ve kollayan -dolayısıyla sosyal ve simgesel sermayeye sahip- bir grup tarafından domine edilmektedir. Zor değişen hiyerarşi ve gelir eşitsizliğinin derinliğini anlatmak için seçilen metafor "kast sistemi" dir. Yerelde eşitsiz ilişkileri betimlemek için en çok vurgulanan nitelik "bölge temsilci"leri ve "muhabir"ler arasındaki gelir uçurumudur:

Gelir...Muhabir mi? Editör mü? Ona göre değiş̧ir. Neden? Temsilcilerle muhabirler arasında çok büyük farklar var. Kast sistemi gibi. Mesela Yeni Asır bölge gazetesi. Yani yerel gazeteyle kıyaslanmaz ama genel yayın yönetmenin bundan kaç yıl önce 20 bin lira maaş aldığı söyleniyordu. Şu an muhabir arkadaşlarım asgari ücretle çalışıyor (...) Yani bir grup var; bu bizim televizyonlarda gördügümüz işte Güneri Cıvaoğlu tarzı. Elinde viskisi, şarabı açıışlarda gezen. İmir'de de var bu: temsilci kesimi. Bir de gerçekten makinası boynunda, asgari ücrete, parçalanmış spor ayakkabılarıyla işte nikon yeleği ile sokak sokak gezen...

GBi: Peki sizce bu temsilci olma, genel yayın yönetmeni olma... bunun şartı ne?

Tanıdık, tanıdık...Bir de şu an özellikle siyasi görüş... Daha önceden de vardı bu yok değildi ama şu an bu daha baskın hissedilebiliyor (Muhabir, 17 Ekim 2017).

Yerelde gazetecilik yapan faillerin özellikle dikkat çektikleri bir diğer nokta, alanda liyakat sisteminin zayıf olmasının nedeninin, sosyal sermayenin kültürel sermayeyi domine ettiği gerçeğidir. Gazetecilere göre meslek pratiklerinde ödül-ceza sistemi zayıftır ve alandaki ekonomik ve simgesel sermaye, sosyal sermaye aracılığıyla aktarılmaktadır. Alan, "çalışanlar" ve "yöneticiler" olarak katı bir ayrıma sahiptir ve bu ayrım kendisini en çok ekonomik sermayenin eşitsiz dağılımında göstermektedir. Nepotizm ve kronizm de, alandaki sermaye dağılımını ve liyakat sistemini olumsuz yönde etkilemektedir:

Gazeteciler orta sınıftan ama tabii o bahsettiğiniz, hani böyle gazetenin yazı işleri, bilmem ne... Onların şeyleri... Onlar artık orta sınıfı çoktan aşmış ve arada uçurumun olduğu... Yani aynı kurum içerisinde... Hani 2 kat, 3 kat, 4 kat falan değil böyle... 30-40 kat maaş farkıııklarının olduğu... Yani gazetecilikte şey vardır, aslında aynı Türkiye gibi; Türkiye'de nasıl orta sınıf yok olduysa, gazetecilikte de bir çalışanlar var, bir de yöneticiler var (Haber Müdürü, 19 Ekim 2017).

Bizim bir dönem stajyerlerimizi zınk diye temsilci yaptılar Ankara'ya falan... Hani, "Aha!.." diyorsun, "Nasıl olur?" falan... Ama sonra bir bakıyorsunuz FETÖ olayları METO olayları... Hoop gidiveriyor... Onların gelişleri gibi gidişleri de çok hızlı oluyor (İstihbarat Şefi, 19 Ekim 2017). 
Gazeteciler tarafından "bölge temsilcileri", mesleki hiyerarşi içinde adaletsiz ödül-ceza sisteminin somutlaşmış halleri olarak değerlendirilir. Bölge temsilcilerinin liyakatları konusunda özellikle muhabirlerin itirazları açıkça dile getirilmektedir. Görüşülen muhabirlerin çoğuna göre, İzmir basını bölge temsilcileri tarafından yönetilmekte ve temsilciler muhabirlerin alandan dışlanmasına dahi neden olabilmektedirler. Bourdieu'ye göre "alanın sahne olduğu mücadelelerin konusu, meşru şiddet tekelini ve söz konusu alan için karakteristik kabul edilen (belli bir otoriteyi) ele geçirmektir, yani en nihayetinde belirli bir tür sermayenin dağılım yapısının muhafaza edilmesi veya alaşağı edilmesi ile ilgilidir (Bourdieu ve Wacquant, 2016, s.139). Gazetecilik alt-alanında, yerelde, temsilciler muhabirlere oranla yüksek ekonomik sermayeye sahiptir, bunun kaynağı ise sahip oldukları sosyal sermayedir. Sosyal sermaye, Bourdieu'nün sözünü ettiği alandaki ilişkisel ağlar içinde, en geçerli sermaye türüdür. Ancak muhabirlere göre bu sermaye alaşağı edilemez, çünkü kendini sıkı sıkıya muhafaza etmektedir. Bu durum herhangi bir alanın işleyebilmesi için "oyunun ve mücadele nesnelerinin doğasına ilişkin içkin kuralları bilen ve ikrar eden habituslarla donanmış, oyuna katılmaya ziyadesiyle hevesli faillerin" (Bourdieu ve Wacquant, 2016, s.138) varlığını tehlikeye düşürür:

Yukarıda..ağalar.. temsilci alıyor 20-25 bin lira..beni burada 20002500 lira paraya çalıştırsınlar, bak çok samimi söylüyorum. Burada da, gerçek anlamda İzmir'de de gazetecilikte yükselme şansın yok. Belli başlı insanlar var. Herkes onları temsilci yapıyor (...) 3-5 isim var. Bunların üzerinde dönüyor.

GBi: Oligarşi gibi mi?

Evet evet! 12 yıldan beri buradayım. Geldiğim gibi, aynı konumda çalışıyorum. Hani bir şeflikti şeydi, yok yani, yok! Yapamazlar. Benim gibi 20 yıldan beri burada çalışan adamlar var. Çok mu başarısızım? Başarısız değilim. Dün gene bir ödül aldım. Hasan Tahsin Türkiye Gazeteciler Fedarasyonu ...Ödüller alıyorsun, ama hiçbir işe yaramıyor, yaramıyor yani.

GBi: Onların oraya gelme nedenleri ne?

$\mathrm{O}$ da artık işverenle ilişkilerinden mi kaynaklanıyor...ya da o cenahın birbirine referans olmasından mı? (Muhabir, 16 Mayıs 2018).

GBi: Temsilcilik liyakata dayalı bir şey mi, yoksa bağlantı, eşdost, çevre? Yani o kişilerin oralarda olmasının nedeni nedir? Yani gazetecilikte 5 yılı geçirdim, artık şunu olmalıyım gibi bir sistem mi? Yok. Tamamen birbirleriyle koalisyon kurmuş. O koalisyonla, işte şunu yönetelim, işte şunu ortak haber yapalım, ezelim, edelim. bu bize reklam vermiyor, yani bu isim olmadığı için veriyorum yani. Yazılmayacağı için söylüyorum (gülüyor). Hep böyle gruplar halinde, birbirleriyle anlaşıp, hatta muhabir transferine bile izin vermeyen, başka gazeteye geçmek için temsilciden izin alan, örneklerini de gördük, yani bizde de yaşandı... öyle bir sistem kurmuşlar (Muhabir, 17 Mayıs 2018). 
Alan içindeki koruma/yıkma stratejileri, iktidar mücadelelerinde alanda sahip olunan pozisyon, meslek içi hiyerarşiyi değerlendirme kriterlerinde doğrudan etkili olmaktadır. Alanda sosyal sermayesi zayıf olan gruplar -özellikle muhabirleralan içi iktidar ve mücadele stratejilerini doğrudan sosyal sermayeye bağlarken, alanda "eski", sosyal sermayesi güçlü olanlar, alan içi liyakatin işlediğine, kültürel sermayenin önemine ve işlevselliğine inanmaktadır. Diğer bir ifadeyle "heteredokslar"/yeniler alanın farklı bir doxa bağlamında yeniden inşasını talep ederken, "ortodokslar"/eskiler varolan normları onamakta, meşru bulmakta ve devamını talep etmekte, dolayısıyla koruma stratejileri geliştirmektedirler. Nitekim bir yerel gazete sahibi/yazı işleri müdürü, "oligarşi" suçlamasını reddeder:

(...)Bölge temsilcilerine gelince, bölge temsilcilerinin hepsinin bir geçmişi var. Mesela Nedim Atilla. Nedim Atilla bir günde Nedim Atilla olmadı. Ben çocuktum. Nedim abi yukarıda Günaydın Gazetesi'nde dirsek çürütürdü. Hamdi Türkmen bir günde Hamdi Türkmen olmadı. Hamdi Türkmen Yeni Asır'da genç bir muhabir olarak başladı. Ama işte o algıda seçicilik var ya..onunla gidiyorsun bir yere. E nerden oradan yukarı doğru gitti?

GBi: Muhabirler hınçlarını yanlış yere mi yönlendiriyorlar sizce?

Bence muhabirler..iyi haber yapmaya odaklanmaları lazım. Şöyle söyleyeyim size..haber paylaşıyorlar. Muhabirler..birbiriyle haber paylaşıyorlar. Neden? O zaman ben neden o adamı tutayım? Sen herkesten farklı ne yazacaksın haberi paylaşıp hep beraber yazıyorsanız? (Gazete Sahibi/Yazı İşleri Müdürü, 17 Mayıs 2018)

Gazetecilerin, yerelde gazetecilik alanının özelliklerine dair tespit ettikleri bir diğer nokta, alanın heteronomisi arttıkça, yani ekonomik baskılar ve özgün habercilikten ambalaj haberlere geçişin yarattığı yapısal sorunlar belirginleştikçe, yerel basının hepten küçülmesi, alanın daralmasıdır:

GBi: Bu kadro daralması daha çok hangi döneme denk düşüyor? Son yıllarda mı?

Evet. Son 10 yılda oldu bu. Ben Yeni Asır'dan ayrılırken, yani bu ne zamana denk geliyor?.. 2008 yılı... 2008 yılının sonu, 2009 diyebiliriz hatta. O dönemde 20-24 tane muhabirimiz vardı.. Bugün gitseniz, tahminim 6 tane muhabir zor çıkar. Ciddi bir düşüş var. Tabii bunda Yeni Asır'ın yeni politikasının da etkisi var. Artık Türkiye haberleri kullanıyorlar. Intiyaç duymuyorlar belki ama... Yine de bir bölge gazetesi için gerçekten az. İşte Doğan Haber Ajansı'na bakıyorsunuz. Son işten çıkarmalarla zannediyorum 3-4... 1 tane de gececileri vardır. Yani 5 tane muhabirleri vardır olsun olsun. Bu bir ajans yani! Doğan Haber Ajansı diyoruz... Yani bizim de muhabir sayımız başladığımıza göre epey azaldı. 3 tane muhabirle idare etmeye çalışıyoruz şu anda. Bizi tabii çok zorluyor.

GBi: Nasıl çareler üretiyorsunuz? 
Şimdi ajansları kullanıyoruz, çok fazla. Biz rutin takip etmiyoruz sadece özel haber yapıyoruz (Haber Müdürü, 19 Ekim 2017).

GBi: Muhabiriniz yeterli mi peki?

Burada yeterli değil, evet. Burada mesela bir ben varım, bir de M. var ekonomi haberleri yapıyor. Ama işte ana gazeteye... Iş̧te cuma günü Cumhurbaşkanı geliyor. Başka bir haber olduğunda, ona ben yönlendiriliyorum bu bölgede. O yüzden de biraz tabii ki şey... Yorucu oluyor, bazı dönemlerde gerçekten yetişemiyorum (Muhabir, 31 Ekim 2017).

Ekonomik baskıların alanı daraltması, rekabet stratejilerinin körelmesine neden olmuştur. Muhabir sayısının azalması ve ambalaj haberlerin artması ile birlikte, rekabet yerini garip bir "dayanışma"ya bırakmıştır. Gazetecilere göre bu "dayanışma", mesleği köreltmekle kalmamakta, alandaki yapısal daralmanın sürmesine de neden olmaktadır:

GBi: Rekabet ilişkileri nasıl gazetecilikte? Yani başka gazeteler, kurum içi...

Ya eskiden öyle idi. Şimdi öyle değil. Az sayıda muhabir var. Yani sahada çok az sayıda insan olduğu için yardımlaşmak zorundalar. Yani ne yapıyorlar mesela?.. Bizim bir muhabirimiz var diyelim, magazine bakan. Ama aynı gece 3 tane iş var. İşleri paylaşıyorlar. Biri bir işe gidiyor, biri bir işe gidiyor ve birbirlerine veriyorlar. Bu yardımlaşmayı herkes biliyor. Tabii gazetecilik böyle bir şey değildir aslında... Yani bir rekabetin olması gerekiyor mutlaka. Fakat özellikle rutin işlerde bu yardımlaşmayı sürdürmek zorunda kalıyoruz. Bu, aynı zamanda ayağınıza kurşun sıkmak gibi de. Yani çok ciddi bir paradoks. Yani biz bunu... Görevleri paylaşıyoruz, paylaştı̆̆ınız için iş yürüyor... iş yürüdüğü için de, "Aa tamam o zaman. Bu kadar az adamla bu iş yapılabiliyormuş" deniliyor ve o döngü böyle, böyle... (Haber Müdürü, 19 Ekim 2017).

Gazetelerin yeterli muhabir kadrosuna sahip olamaması, "bülten gazeteciliği" ya da "ambalaj haber" denilen, belediyeler, valilik ya da sivil toplum kuruIuşlarının basın birimlerinin elinden çıkmış hazır haberlerin doğrudan kullanıımasına neden olmaktadır. Bu durum, kimi rutin haberler için olağan görülebilirse de, bütünlüklü bakıldığında gazetecilik alanının otonomisini zedeleyen, onu bağımlı kılan ve yaratıcılığını olumsuz etkileyen bir süreç olarak yorumlanabilir. "Gazetenin gözü" olarak kenti dolaşan, insanlara temas eden, belediye/valilik vb. resmi kurumlarda kaynaklarla doğrudan temas içinde olan, haberi bağlamsal düşünüp değerlendirebilen muhabir profilinden, gazeteye gelen ambalaj haberleri servis eden masa-başı elemana dönüşen muhabir, meslek içi statüsünü de bu nedenle yitirmektedir. Editör ve sayfa sekreteri, hatta reklam bölümleri muhabirden daha önemli hale gelmiştir. Alandaki bu daralma, ekonomik ve politik açmazların iç içe 
geçmesiyle, gazeteciliğin son yıllarda içine düştüğü zor durumun yansımasıdır. Varlığını resmi ilan, belediye desteği ya da ana gazetenin lütfuna borçlu olan yerel gazetecilik, etkili okur desteği de bulamayınca iyice küçülmüştür.

Yukarıda sözü edilen sorunlar alt-alan olarak yerel basın yanında, gazetecilik ana alanının da sorunlarıdır. Gazeteciliğin meslek olarak işsizlik oranı en yüksek iş kollarından biri olması ve iletişim fakültelerinin hızla artan sayısı nedeniyle alana girişlerin istenilen düzey ve kapasiteden fazla olması, alanın sınıllarını failler aleyhine daraltan sonuçlara neden olmuştur. ${ }^{2}$ Alanda halihazırda çalışanların ise, alanın illusio'suna olan inançları gittikçe azalmaktadır. Alandaki faillerin stratejileri bağlamında bakıldığında, gazetecilik bir an önce içinden çıkılması, kaçılması gereken bir meslek olarak görülmektedir. Bourdieu'nun alan içinde baskın iki strateji tanımladığı düşünüldügünde (koruma [ortodoksi] ve yıkma [heterodoksi]), "alandan kopma ve kaçış", alan için yıkıcı üçüncü bir strateji (irtidat [apostasy]) olarak belirmektedir ${ }^{3}$. Bu durum, faillerin artık oyunun illusio'su ile ilgilenmediğini, oyunu oynamaya değer görmediğini gösterir. Yerel basın bağlamında, alandan kopan gazeteciler, belediyelerin basın büroları tarafından "kapılmakta"; güvenli bir memuriyeti, riskli ve etkisiz gazetecilik alanına tercih etmektedirler:

Şu an İzmir'de belediyelerdeki muhabir kadrosu bütün gazetelerden daha güçlü. Yani en iyi gazeteciler şu an ya belediyelerde, ya da Ticaret, Sanayi Odası...Sivil toplum örgütlerinde çalışıyorlar. Dolayısıyla onların gönderdiği bültenler, haberler hiç sorgulanmadan doğrudan sayfalara konuluyor (Muhabir/Köşe Yazarı, 15 Mayıs 2018).

Kimse artık gazetecilik yapmak istemiyor. Yani biz konuşuyoruz, emekliliğimizi bekliyoruz. Hatta acaba emekli olmadan da tazminatımızı alabilirsek eğer, ayrılsak mı diye konuşuyoruz. Belki mesela tamam hasbelkader bu işe, gazeteciliğe başladım. Fakat her zaman çok büyük bir aşkla yaptım. Hiçbir zaman pazartesi sendromu diye bir şey yaşamadım. Hep koşarak işe geldim. Hep bir heyecan vardı, bilmem ne. Bu artık son 3 senedir... Bu işten artık nefret eder hale geldim ve bir an önce artık başka bir şey yapayım diye düşünüyorum ve bulduğum ilk fırsatta ayrılacağım işten (İstihbarat Şefi, 19 Ekim 2017).

2 TÜiK verilerine göre üniversite bölümleri arasında en çok iş güvenliği, sosyal hizmet, sanat, bilişim ve gazetecilik mezunları işsizdir. http://www.tuik.gov.tr/PreTablo.do?alt_id=1007, http://www. nkariyer.com/haber/gundem/2018/5/22/issizlikteki-cok-carpici-detaylar-iste-en-cok-issiz-mezun-olan-bolumler (erişim tarihi: 29.06.2019)

3 Koruma (conservation) ve yıkma (subversion) stratejilerini, Hristiyanlıkla kurduğu analoji ile Bourdieu ortodoks ve heretik tavırlar olarak adlandııı. Alandan tamamen çıkma ile ilgili bir kavramsallaştırması bulunmamaktadır. Oysa gazetecilik alanı düşünüldüğünde, bu strateji alanın niteliğini doğrudan yansıtır ve alanın içinde bulunduğu kriz ile ilgili çok şey söyler. Bu üçüncü yol, önceki analojiyi izleyerek irtidat-mürtedlik (apostasia, apostasy, aversion) olarak tanımlanabilir. Bu kavram, dinden tamamen çıkmayı, başka bir dine girmeyi ya da dinsizliği tercih etmeyi anlatır. Alan içi yorumladığında, gazetecilik öncesi durumuna dönme, meslek dışı kalma ya da başka bir alana girişi anlatabilir. 
GBi: Peki bu bahsettiğiniz sıkıntılara bakarsak, gelecekte kendinizi gazeteci olarak tahayyül ediyor musunuz?

Başka bir planım var: Köy kahvaltısı işine girmek istiyorum. Gerçekten. Tarhana, tereyağı falan...Beklerim... (gülüyor) (Muhabir, 17 Ekim 2017).

Alanı tamamiyle terketme (irtidat-apostasy), faillerin kuvvetli biçimde arzu ettikleri bir tercih olsa da, alan içinde kalma ve koruma (conservation) stratejileri kendisini dayatmaktadır. Alan içinde kalanlar için oyun, politik/ekonomik iktidar alanının talepleri doğrultusunda şekillendirilen, "uzlaşmalar" ile sürdülen sözde bir uğraş halini almıştır artık. Doxa'nın (-kabul edilmiş kurumsal roller, epistemolojik çerçeveler ve etik standartlar - Vos ve Craft'dan akt. Stringer, 2018) heteronomi nedeniyle dönüşümü, mesleği icra edebilmek için verilen tavizler ve etik dışı ilişkileri gündeme getirir. Alanın yeni doxa'sına yönelik eleştirel bir tavır dikkat çekse de, koruma stratejileri yeni doxa'ya uyumu, dolayısıyla onun yaratacağı sembolik iktidarı beraberinde getirir:

GBi: Peki bu dış müdahalelere karşı geliştirilmiş stratejiler var mı? Karşı stratejiler?

Şimdi bazen muhalif bir haberi verebilmek için... Aynı zamanda... Doğrudan hatta şöyle söyleyeyim, yalakalık haberi de yapıyoruz. Yani ikisini birden veriyoruz ki...Dengede duruyormuş gibi gösterelim kendimizi (Haber Müdürü, 19 Ekim 2017).

Şimdi maalesef öyle bir noktaya geldik ki habere gittiğimiz zaman bir kişi yazıyor, diğer hepsine mail atıyor, bunu bizler de yapıyoruz. Yani özel haberlerde değil, mesela basın toplantısı. Yani fotoğraf bile çekilmiyor. Biri çekiyor veya basın danışmanından alıyorsun. Bir kişi yazıyor, herkese mail atıyor, sadece girişini ve başığını değiştiriyor, aynen giriyor (Muhabir, 16 Mayıs 2018).

Gazetemizin ayakta durması lazım (gülüyor). Yani benim çalıştığım gazete dediğim gibi, İzmir'de bu işlerden biraz daha arınmış. Biraz daha rahat. Mesela ben hiçbir zaman ilan istemedim, reklam istemedim, hediye istemedim ya da başka bir şey. Ama benim arkadaşlarım şunlara maruz kaldı: Sallıyorum balık festivali ya! Balık festivali yani. Sardalya. Yani bu kadar mı küçülür bir insan?.. Işste gazeteye 5 kilo balık sallıyorum... Tabii bu şey... Ya bu... (gülüyor) Tabii bunun büyüdüğünü düşünün.

GBi: Bir fayda sağlayabilmek yani. Ucundan kulağından...

Bu pastanın dilimi büyüdükçe, oyuncuları zenginleştikçe, işlerin değiştiğini düşünün. Yani bu böyle gidiyor, kartopu gibi büyüyor falan. Ben yaşamadım. Ama yaşayan, yaptığı haberi şantaj malzemesi 
olarak kullanılan arkadaşlarım oldu. (Muhabir, 17 Ekim 2017).

Alanın doxa'sındaki dönüşüm, kurumların benimsedikleri roller ve etik standartlar bağlamında da ele alınabilir. Faillere göre, kurumlar zayıf, yetersiz ve kimi zaman da nesnel normlardan uzak işlev görmektedir. Birbiriyle bağıntısallık içinde, alanın kültürel sermayesini ve otonomisini koruyacak biçimde çalışması gereken kurumların yetersizliği, faillerin illusio'yu sorgulamasına neden olur:

5 yıl gazetecilik yaptım ve sendikaya kesinlikle bütün ısrarlara rağmen üye olmadım. Bununla ilgili de kesinlikle patronumdan duyduğum çekince yoktu. Benim patronum sendika üyesiydi. Ondan sonra... Sendika başkanı yani İzmir başkanı gelip, "şöyle falan" dediği zaman, ben dönüp patronuma, "Benim bir sıkıntım olursa sizinle direkt konuşurum zaten" diyebilecek kadar da rahat bir insandım. Ne oldu? Bir yıllık izinle ilgili sıkıntı oldu. Açtım, benim okuma-yazmam var Allah'a şükür. Basın İş Kanunu'ndan ne olması gerektiğini okudum. Bu patronumu rahatsı etti. Ondan sonra...

G: Kendi kurallarını uygulamak istiyor yani.

Tabii ki yani. Benim 10 günüme el koyacak. Ondan sonra neyse... Kimi ararız? Sendika başkanını ararız ve patrondan yana tavır aldı. Şimdi benim önümde Basın İş Kanunu varken, ben sana mı inanırım?.. O gün nasıl olduysa adam bizi ziyarete geldi o tartışmanın üstüne. Evirdi, çevirdi, kıvırdı. Ondan sonra ben ne o adamın grubunun içinde yer alırım ne de onun verdiği sözlere inanırım (Muhabir, 17 Ekim 2017).

Gazeteciler Cemiyeti'ne gelince... Tüm gazetecileri temsil edebiliyor mu?.. Onda kuşkularım var çünkü... Şimdi "Gazeteci kimdir?" sorusuna verilen yanıt...Gazeteciler Cemiyeti için ve benim için aynı şeyler değil. Gazeteciler Cemiyeti diyor ki: "212 sayılı yasaya bağı olan kişi, işte sarı basın kartına sahip olan kişi gazetecidir" diyor. Valla ben öyle demiyorum. Benim için sokakta olan kişi, haber peşinde koşan kişi, aynı zamanda bu haberin gazetede yayınlanmasına kadar, gazetede, televizyonda neyse yayınlanmasına kadar geçen süre işte. Emek harcayan her kişi, gazeteci (...) Mesela TRT'de ışıkçılar, setçiler, bilmem neciler de 212'de ve basın kartları var ve onlar da gazeteci geçiyor. Onlar da Cemiyet'e üye. Gazeteci kimliğiyle üye! Ama sokakta haber peşinde koşan, gazeteci diye kabul edilmiyor. (Istihbarat Şefi, 19 Ekim 2017)

Bizim kurumda mesela Gazeteciler Cemiyeti var, kendilerine karşı olan kurumdakiler, eleman çıkardığı zaman yazılı açıklama geçerler, ama kendilerine yakın olanlar eleman çıkardığı zaman hiçbir şey yapmazlar. Onlar dahi taraf tutuyor. Biz işte küçülmeye gittik. 
...Çıkardıkları zaman..Geldiler, selam verdiler gittiler. Hiçbir yazılı açıklama yapmadılar. (Muhabir, 16 Mayıs 2018)

İşten çıkarılanlar oldu. Insanlar eleştiriyordu. Şuna da mesela sinir oluyorum. Yandaş mandaş diyorlar, şey yapıyorlar ama bizim işte diyorlar ki yandaş medya 3 kişiyi çıkardı. 5 kişiyi çıkardı bilmem ne. E kendilerinden çıkarıınca da hiç kimsenin de sesi çıkmıyor yani. Bir ara sol cenah bir şey yapıyor, hani bakıyorsun Cemiyet'in 9 Eylül Gazetesi'nden adam tık diye, Hürriyet'ten, Mustafa Abi'yi mesela çıkardılar, çeşitli sol görüşlü gazetelerden de oluyor yani. Hep bir şey var hani: sol taraf hep sağı eleştiriyor ama solda da var hani. Ben illa sağcıyım diye bunu söylemiyorum da. O taraf sanki hep biz iş emek, özgürlük hani, o taraf daha çok savunuyor ama kendi şeylerine gelince yeteri kadar hani şey yaptıklarını düşünmüyorum. (Muhabir, 16 Mayıs 2018)

Gazetecilik; alanı daralmış, otonomisi zayıf, etkisiz, liyakat sistemi sorunlu biçimde tasvir edilmekle birlikte, bu tanımlama son beş yılda kendisini iyice hissettiren, ancak 2000'li yılların başına tarihlenen bir dönemi anlatmaktadır gazeteciler açısından. Alanın geçmişini bilen daha deneyimli gazeteciler, gazeteciliği simgesel sermayesi gittikçe zayıflayan bir meslek olarak görseler de, kuvvetli bir nostalji duygusuna da sahiptirler. Gazetecilerin daha etkili olduğu, alanın bugüne kıyasla çok daha otonom olduğu, ekonomik sermayesi hiçbir zaman güçlü olmasa da toplumda simgesel sermaye bağlamında güçlü bir meslek olarak gazetecilik imgesi, bu belleğin ortak temalarıdır:

GBi: Peki geçmişten bugüne gazetecilikte ne değişti? Yani politik baskı, ekonomik baskı, mesleğin işleyişi, insanlar? Kurum, okurlar?

Ben 93-94'te mesleğe girdiğim zaman, gazeteci dediğin zaman insanlar ayağa kalkar, kapıda karşılardı. Ama bu dönemde senin telefonuna dahi çıkmıyor, dönme gereği bile duymuyor. Neden? Bir güce güveniyor. $O$ güç arkasında olduğu için, sen onu yazamıyorsun. Daha önce bir emniyet müdürü veya bir vali sana bir şey sorsun, onu manşet yapabilirdin. Onu görevden aldırabilirdin, yaptığın haberinle. Ama bunu sorgulayacak ya da yazacak kalmadı. Yani yazamıyorsun. Bu korkudan mı diyebiliriz, koltuğu korumak için mi, yoksa ister istemez sistem otomatik böyle mi yürüyor? Yani siyasi baskıdan dolayı. Bundan dolayı yapamıyorsun, yazamıyorsun, eleştiremiyorsun. E okuyucu da eskisi gibi sahip çıkmıyor. Yani o gazetenin kokusunu alıp, ekmeğiyle birlikte gazete alan okuyucu yok (...) Haber yok. Köşe yazarları taraf tuttuğu için, okuyucuya verdiği bir şey yok. Ben hiçbir köşe yazarını okumuyorum mesela..

GBi: Ne zaman başladı bu süreç?

En az 10 yıl vardır ya (...)Uğur Dündarlar falan, Show TV'deki Reha 
Muhtarlar falan, yan tarafta adam rüşvet alırken canlı canlı yayınladı. Şu anda yapamazsın. O gücün de yok, o şeyin de yok yani. Korkun var. Yapamazsın (Muhabir, 16 Mayıs 2018).

İşte gazetecilik kültürü değişiyor... Dediğim gibi, şimdi bir muhabir, bir Büyükșehir Belediye Başkanı'nın karşısında korkuyor artık. Anlatabiliyor muyum? Eskiden Büyükşehir Belediye Başkanı korkardı muhabirden (Istihbarat Şefi, 19 Ekim 2017).

Kaç yıldır bu işi yapıyorum? 23, 24. yıldayım, bu işi yapıyorum. Eskiden tamamen inisiyatif muhabirdeydi. Bir şeyi buldun; tut, getir, et. Sen gazetecisin. Zaten bunu engellemek diye bir şey söz konusu olmazdı. Ama evrildi gazetecilik. Son yıllarda çok hızlı bir evrilmeden geçtik. Yani 10-15 yıl içerisinde. Mesela Ankara'daki İstanbul'daki gazetecileri bilemem. Eskiden de belki oradakiler çok büyük siyasi baskı altındaydı (...) Ama, İzmir'de gazetecilikte, biz bunu hiçbir şekilde hissetmedik. O, mesleğe başladığım yıllarda, sonraki yıllarda, 2002'lerde Yeni Asır'da başladığım o yıllarda... Bazen arşive bakıyorum öyle haberler yapmışız ki, çataçat yazmışız yani... (Istihbarat Şefi, 19 Ekim 2017).

Yerelde gazetecilik yapmanın temel özelliklerinden biri, bir "merkez" olarak kodlananın dışında, onun periferisinde varolmak zorunluluğudur. İzmir için merkez öncelikle İstanbul, sonra Ankara gazeteciliğidir. İstanbul ekonominin, Ankara bürokrasinin/siyasetin başkenti olarak, haber kaynaklarına yakınlık bağlamında merkezdir. Merkez-çevre ilişkisinde İzmir'de haberciliğin avantaj ve dezavantajları, merkezin çevreye yaklaşımı sorulduğunda, gazetecilerin alana dair tanımlamaları hem alana giriş, hem de alanda gerekli sermaye türleri bağlamında değişiklik göstermektedir. Görüşme yapılan gazeteciler açısından İstanbul ve Ankara'da habercilik, her ne kadar sosyal sermayenin önemli olduğu bir alan olsa da, kültürel sermayenin daha gerekli görüldüğü, haberciliğin hem örgütsel hem mesleki anlamda daha profesyonel olduğu,bu nedenle de eğitimli gazetecilere gereksinimin daha fazla hissedildiği bir deneyimi tanımlar. İzmir'de haber kaynaklarına erişim azdır. İstanbul ekonomi, Ankara siyasetin merkezi olarak, ekonomi ve iktidar alanlarına yakınlığın sunduğu farklı sermaye türlerinden yararlanırken, İzmir her iki alanda da daha güçsüzdür. Yerelden merkeze en çok geçilen haberler polis-adliye ya da insan haberleridir. İzmir bu dezavantajları nedeniyle, çoğu kez "taşra" ya da "köy" olarak tanımlanır. "Gerçek gazetecilik" yapmak için, İstanbul'a gitmek gerekmektedir. Yerel basının sembolik sermaye bağlamında zayıflığı düşündürücüdür ve bu zayıflık tarihiyle çelişmektedir (bkz, Gezgin, 2007). OsmanIı İmparatorluğu'nun çöküş sürecinden Kurtuluş Savaşı'ndaki etkisine, Demokrat İzmir ve Yeni Asır tecrübelerinin tarihsel birikimine karşın, İzmir basını merkez karşısında kendisini etkisiz görmektedir. Bunun önemli nedenlerinden biri kent olarak İzmir'in belirleyiciliğini, etkisini yitirmesidir: 
İzmir'e dönmüş ağabeylerimiz İzmir'e köy der. Ben de ulusal kesimi etkileyecek haberler nezdinde, İzmir'in çok eksik olduğunu düşünüyorum. Aşırı eksik olduğunu düşünüyorum yani (...) Bana şunu söyleyen oldu, "Sen okuyan, araştırmayı seven bir kardeşimizsin. Bence İstanbul'a git. Burası boş." Şöyle bir durum var: şu an ben 25 yılını doldurmuş ve Cemiyet'te işte 25 yıldır gazetecilik yaptığı için ödül almış bir ağabeyimizle de aynı maaşı alıyorum. Yani hiçbir gelişme kaydedememiş yani. Başladığı yerde adam... Maddi olarak (Muhabir, 18 Ekim 2017).

Günlük tempoda biraz daha İmir'deki muhabirler daha yerel düşünüyor. Bir de atıyorum, İstanbul'da da böyle bir bakış açısı vardır: Aziz Kocaoğlu bir şey derse o kadar önemli olmaz ama Kadir Topbaş derse daha önemli... (İstihbarat Şefi, 19 Ekim 2017)

Yani İstanbul ve Ankara ile karşılaştırıldığı zaman İzmir'de çok taşra mantığıyla gazetecilik yapılıyor. Bir kere, ulusal kurumlar bile olsa buradaki, bölgedeki yapılanmaları hep arka plana atıyorlar. Yani burası unutuluyor (...)Bunu belki ilişki olarak, buradaki yöneticiler yapıyor olabilir. Biraz daha... Buranın eti, sütü kendine kalsın yani. Çok fazla ekonomi gazeteciliği gibi geliyor bana. Yani işte çok fazla bülten-belediye gazeteciliği... İşte belediyeler ne gönderirse sana işte firmalar sana ne gönderirse o hazır (Muhabir, 31 Ekim 2017).

İstanbul ve Ankara'nın gazeteciliğin merkezleri olarak kodlanması, akla periferide kalanların algılanma biçimini getirmektedir. "Taşra", merkezin kendisini algılama biçimini nasıl görmektedir? Araştırma sonuçlarına göre, merkez/taşra diyalektiği, merkezdekilerin taşradakiler üzerinde kurduğu açık bir tahakküm biçiminde işlemez. Görüşme yapılan gazetecilere, kendilerine yönelen açık bir ayrımcılık olup olmadığı soruldu. Alınan yanıtlar, "liyakat" şüphesine dayalı, dolaylı ve kısmi bir dışlamaya işaret etmektedir:

GBi: İstanbul ya da Ankara'dan gazetecilerle ilişkileriniz nasıl? "Taşralı" yaklaşımı var mı?

Ya öyle bir algı olmuyor. Neden? Çünkü birebir iletişimleriniz olmuyor zaten onlarla. Ama aynı bakış açısını hissediyorsunuz tabii. Ya da ne bileyim İzmir'de çok önemli bir şey olunca, bazen İstanbul'dan adam gönderiyor. E tabii İzmir'deki diyor ki: Bir dakika ya! Biz bütün yıl çile çekmişiz hani (gülüyor). İlk defa düzgün bir haber var. Niye İstanbul gelecek? Ben bu işi kotarır, gönderirim sana (...) ama bu asla ben hiç tanık olmadım hani bir gerilim, bir çatışma ortamı... Çünkü birebir, bir muhatabiyetiniz yok zaten (İstihbarat Şefi, 19 Ekim 2017).

Mesela diyelim ki Soma'daki maden faciasını düşünürsek, buradan iki 
arkadaşımız gitti, İstanbul'dan başka iki arkadaş geldi ve aralarındaki iletişim gayet iyiydi. Herkes birbirlerini tanıyor, seviyor falan bunda bir sıkıntı yok. Fakat yine de... Taşra muhabirlerini -kendimizi de aynı şekilde nitelendiriyorum- taşra muhabirlerinin kafasında bir soru işareti var: "Ben burada dururken neden İstanbul'dan birini gönderiyorlar. Ya da neden İzmir'den birini gönderiyorlar?" gibi bir soru bu. Haklılar da bir yandan.... (Haber Müdürü, 19 Ekim 2017).

Görüşme yapılan gazetecilere göre, İzmir'de gazeteciliğin tek avantajı, haber kaynaklarının kıtlığının, muhabirleri yaratıcılığa ve habercilik reflekslerini sivriltmeye sevk etmesidir. İzmir'den Ankara ve İstanbul'a giden gazetecilerin yaygın başarısının arkasındaki neden, kentin imkansızlıklarını habere dönüştürmedeki maharetleri olarak görülür. Merkezde son yıllarda yaygınlaşan, gazetecilerin muhabir-editör-fotoğrafçı olarak habercilik pratiğinin her aşamasında iş görmesi, İzmir'de uzun yılların pratiğidir:

İzmir'den çıkan gazetecilerin hepsi -ilginçtir- çok başarılıdır. Çünkü yerelde haber bulmak daha güçtür. İstanbul kadar ya da Ankara gibi parlamentosu, bilmem nesi yok. İstanbul gibi büyük nüfuslu bir kent değil. Burada tırnaklarıyla kazıyarak haber bulmaya alıştığı için, İzmir'den İstanbul'a ve Ankara'ya giden muhabirler çok başarılı olurlar. Çünkü, "bu kadar çok haber içinde nasıl haber yapamazlar" diye dehşete düşerler (gülüyor) (İstihbarat Şefi 19 Ekim 2017).

(...) Gidiyordum haberi yapıyordum, görüntüyü ben çekiyordum, yani aynı zamanda kameramanlık yapıyordum. Geldiğimde haberi yazıyordum. Hatta yeri geldiğinde montaj bile yapıyordum. Noldu? 3 kişi: muhabir, kameraman, montajcı oldum ben. Hatta editör bile. Ama İstanbul'a gittiğinizde, herkes, profesyonellik falan... Hani burada bir rekabet var İzmir'de. Hani atıyorum insanlar da o kadar şey ki..tabir nasıl olur? Çakal mı diyeyim (gülüyor), çok uyanık mı diyeyim, belli muhabirler var. Bunlar da zaten polis muhabirliğinde yetişiyor. Ben polis muhabirliğinden geldiğim için işin şeyini de gerçekten öğrendim hani. Hani uyanıklıı̆ını, çakallığını öğrenme şeyin daha fazla..çünkü küçük yer olduğu için, bir şey gibi bir ceylan düşünün, herkes onu parçalamaya çalışıyor (gülüyor) (Muhabir, 16 Mayıs 2018).

\section{Sermaye Türleri ve Dağılımı}

Görüşme yapılan gazetecilerin geneli kültürel ve ekonomik sermaye bağlamında zayıf bir ardalana sahiptir. Aile geçmişleri incelendiğinde; anneler ev hanımı (1'i hariç), babalar ise işçi (2), asker (1), esnaf (kabzımal/oto tamircisi/dükkan sahibi) (4), çiftçi (2), gazeteci (1), hastane yöneticisi (1) olarak dağılmaktadır. Sadece bir gazetecinin ebeveynlerinin ikisi de yüksek öğrenim görmüştür. Üç gazetecinin 
anneleri okuryazar değildir. Babaların geneli ortaokul ya da lise mezunudur. Gazeteciler, kişisel hikayelerinde eve gazete girdiğinden, gazetenin baba tarafından okunduğundan, çocukları okutmaya verilen önemden ve gazeteci kimliğine duyulan saygıdan söz etmişlerdir. Bu bağlamda ailelerin kültürel sermayeye verdiği önem dikkat çekicidir. Meslek olarak gazeteciliğe giriş, çoğunlukla ikincil bir tercih olarak şekillenir. Hukuk, dramatik yazarlık, spikerlik, askerlik birincil tercihlerdir. Eğitim sistemi (üniversite sınavında yaşanan aksilikler) gazetecilerin meslek seçimini olumsuz yönde etkilemiştir. Görüşülen kişilerden sadece üçü, seçtiği için ve birinci tercih olarak gazetecilik yapmaktadır. Üç gazeteci hariç tamamı iletişim fakültesi mezunudur (bu üç gazeteciden biri açık öğretim, diğerleri finans ve dramatik yazarlık mezunudur). Bu dağılım, kültürel sermaye bağlamında güçlü ve yetkin bir grubu akla getirmektedir. Ancak buna rağmen gazeteciler, genellikle mecbur kaldıktan sonra gazeteciliğe ısınmış, mesleğin simgesel sermayesini içselleştirmişlerdir:

O zamanlar idolümüz tabii Uğur Mumcu. İmza günlerine giderdik. Işste Abdi İpekçi. Gazeteci deyince tabii o dönem, "Sorunları yazan, araştıran, topluma ciddi olarak hani yön veren, sorunları dile getiren..." yani bence o etkili oldu. O yüzden de hukuk, siyasal olmayınca, gazeteciliği de zaten istiyordum, heralde etkisi oldu (Muhabir/Köşe Yazarı, 15 Mayıs 2018).

(...) Hukuk fakültesinde okumak istiyordum. İlk tercihlerim de o yöndeydi zaten. Ama olmadı (...) Üniversiteye geldim zaten bir hayal kırıklığı yaşadım, onu söyleyeyim, şu fakülteye geldim, aaa ben nereye geldim dedim. Zaten ilk üç sene hiçbir şey yapmadım. 3.sınıfın sonlarına doğru derse bir gazeteci abimiz geldi, duayen diye kabul ettiğimiz, Cemalettin Özdoğan vardı. O bizim derse geldi ama bizim zaten derslere çok şeyimiz yoktu. Ben kafamda bir gazeteci olacağım gibi bir hayalim yoktu yani (...) O bir gün derse geldi. Ben de tesadüfen girdim.. Onun anlattıklarından bir anda etkilendim. Ertesi gün gittim Hürriyet Gazetesi'ne. Gece muhabiri adam arıyorlardı. Bir anda yani.. (Muhabir, 17 Mayıs 2018).

Gazetecilere alana girişte belirleyici olan sermaye türü sorulduğunda, çoğunun ortak görüşü, gazeteciliğe başlarken sosyal sermayenin önemli olduğu, ancak gazeteciliği sürdürebilmek için bunun yeterli olmayacağı ve kişinin habitusunun mesleğe uygunluğunun daha önemli olduğudur. Gazeteciliğe başlarken tanıdık, eş-dost tavsiyesi hızlandırıcı bir etken olsa da, gazetecilikte uzun süre tutunmak ve bu mesleği icra edebilmek, merak, ataklık, girişkenlik vb. bireysel niteliklere bağlı bir yetenek olarak düşünülür. Bu değerlendirmeler, akla Bourdieu'nün [(habitus)(sermaye)] + alan= pratik (Bourdieu ve Wacquant, 2016) formülünü getirir. Buna göre alandaki her unsur, pratiği şekillendirmek üzere "bağıntısal" işler. Kültürel sermaye alanda gerekli, ancak özellikle yerelde kimi zaman "ihmal edilebilir" bir unsur olarak yorumlanmaktadır. Özellikle "iletişim fakültesi" mezunu olmanın, 
özgün bir kültürel sermaye niteliği olarak, alana girişlerde çoğu zaman önem arzetmediği düşünülmektedir. Bu bağlamda alana girişlerin dışlama-sınırlama stratejileriyle belirlenmemesi, alana yeni katıımları artırmaktadır (alanın sınırları için bkz. Kaya, 2016, s.408):

Eğitim, mesela bir gazeteci olmak için sıralanacak bir listede herhalde son sırada... Yani bir üniversite, eğitim anlamında tabii üniversite mezuniyeti aranır. Sonuçta orada... hani iletişim fakültesi mezunu olsun, bilmen ne. Bu bir artıyla başlamıyor. Bizim mesela gazetelerde çalışan sinema televizyon bölümü var, fotoğrafçılık var, güzel sanatlar var, uluslararası ilişkiler var. Mesela bizim haber merkezinde bile saydığım zaman, iletişim fakültesi mezunu işte bir M. var, M. ve ben varım yani (İstihbarat Şefi, 19 Ekim 2017).

Valla bence... İmir gibi yerlerde eğitimin çok fazla bir önemi yok. Burada yapılan şey tabii yerel gazetecilik. Onun için işte bir yabancı diline, işte efendim ne bileyim böyle çok iyi bir entelektüel birikime intiyacınız yok. Yani sonuçta burada birlikte karşı karşıya olduğunuz insanlar ve polis haberleri yapıyoruz, insan haberleri yapıyoruz, politik haberler yapıyoruz ama yerel politika haberleri bunlar... (...) Kişilik özelliği daha önemli... Yırtık olması, atak olması, sorgulayıcı olması, meraklı olması bunlar önemli. İstediğiniz kadar iletişim fakültesi... 10 tane bitirin, dünyanın en iyi iletişim fakültesini bitirin ama eğer sessiz, sakin, içine kapanık ya da umursamaz bir şeyiniz varsa -kişiliğiniz varsa- gazetecilik yapamazsınız (Muhabir, 31 Ekim 2017).

GBi: İşe başlarken tanıdık mı eş dost çevre mi, eğitim mi önemli? Kişisel fikrimi sorarsanız, çevre önemli. Hani yüzlük bir şey düşünürseniz, $\% 70$ çevre, $\% 30$ da hani meslekle okulla alakalı bir şey. Belki \%25 bile olabilir (Muhabir, 16 Mayıs 2018).

Şu anda staj yapanlara bakıyoruz. Staj için bile torpil aranıyor. Staj için bile ya..gelecek 3 ay staj yapacak, para vermiyorsun, hiçbir şey yapmıyorsun. Onun için bile birilerine referans ve torpil gerekiyor (Muhabir, 16 Mayıs 2018).

Bourdieu, alanların yapısal işleyişinde, alana giren kişi sayısının dahi önemli olduğunu belirtmektedir. Alandaki fail sayısı arttıkça, iktidar ve tahakküm ilişkileri de bu olguya göre biçimlenmekte, sermaye biçimleri ve dağılımı değişmektedir. Kaya'ya göre alanda üretim yapan nüfus arttıkça, mevcut hiyerarşik yapıyı korumanın önemi ve aciliyeti artmaktadır; çünkü böyle durumlarda alan harici etkilere daha açık hale gelmektedir. Alana ilk defa katılanlardaki önemli bir demografik artış; alanda alışılagelmiş işleyişin mantığını tersine çevirebilmektedir (Bourdieu, 1996'dan akt. Kaya, 2016, s.410). Kişi sayısı arttıkça rekabet ilişkileri çalışanlar 
aleyhine işlemekte, alanda uzmanlaşma eksikliği, gazeteciliğin kültürel sermayeye gereksinim olmayan bir meslek olarak algılanmasına neden olmaktadır. Kurallar açık ve kesin olarak kodlanmadığı için, bu alanların sınırları geçirgen ve akışkandır; konum ve meşruluk tanımları ise esnek ve çeşitlidir (Kaya, 2016, s.410). Yetenek, uzmanlık ve bilgide cisimleşen kültürel sermayenin, alana nihai otonomi ve gücünü verdiği düşünüldügünde (akt. Stringer, 2018), alanın sınırlarının esnekliğinin, gücünü azalttığı varsayılabilir:

Bir kere gazeteci sayısının çok olduğunu düşünüyorum. Herkes gazeteci olmuş. Ya ben size söyleyeyim, şu anda gazetelerde daha önce gazetede şoför olarak çalışmış adam var. Yani bunu biz biliyoruz, bütün gazeteciler de biliyor. Yani kendi şoförünün eline kamerayı vermiş, çektirmiş (...) iki yıl sonra muhabir eksik olmuş, gitmiş ben çalışırım demiş, iki sene sonra yan yana fotoğraf çekiyoruz, basın toplantısındayız. Bunu nasıl açıklayacaksınız? Bakıyorum sağımda o var. Bugün de hala çalışan var öyle, bizim birlikte şey yaptığımız. Daha önce ulaştırma servisinde çalışan, şimdi muhabir olan. Kameraman olan, fotoğrafçı olan. İzmir basınında var, ulusal basında da var. Konuşuluyor. Sosyal medyalarda dönüyor. Öyle olunca adam niye iletişim fakültesi okusun ki? (Muhabir, 18 Mayıs 2018).

Kültürel sermayeye gereksinimin görece eksik görüldüğü gazetecilik alanı, bununla bağlantıı olarak simgesel sermayesi de eskiye göre zayıflamış bir meslek olarak algılanmaktadır. Gazetecilik, "fark yaratma", "sorunlara somut çözümler bulma", "sarı basın kartı" ile toplum nezdinde itibar sahibi olma ve saygı görme bağlamında gazeteciler tarafından hala "karizmatik" olarak algılanan bir meslektir. Ancak, özellikle son yıllarda gazetelerin yitirdiği otonominin, alana yönelik olumsuz yargıyı pekiştirdiği ve gazetecilerin simgesel sermayesini azalttığı düşünülmektedir. Gazetecilerin kendi kişisel öykülerinde de, toplumun mesleğe bakışında da öne çıkan "imaj", Siyaset Meydanı/Ali Kırca ya da Arena/Uğur Dündar modeli popüler bir araştırmacı gazeteci tiplemesidir. Burada kültürel sermayesini, ekonomik ve sosyal sermaye ile birleştirmiş, sosyal sorunlara duyarlı bir gazeteci profili öne çıkar:

GBi: (...) Acaba neden karizmatik bir meslek olarak algılanıyor gazetecilik?

Örnekler öyledir. Yani işte ölen gazetecilerin arkasından şarkılar yapılması, kitaplar yazılması, gazetecilerin ciddi kitaplar yazması... Sürekli okuyan, tartışan, eden... bir de bizim evde çok da şey izlenirdi, Siyaset Meydanı tarzı programlar. Orada da hep gazeteciler çıkar yani, tek kimlik...(Muhabir, 18 Ekim 2017).

GBi: Mesleğe yönelik algı ne durumda?

Hayranlık var hâla... Yani hâlâ bir hayranlık var.

GBI: Onun nedeni nedir sizce? 
Toplumumuzda bizim gazeteciliğe karşı inanılmaz böyle bir sempative hani çok işte... "Heyecanlı, aksi..." Hep böyle... Belki de filmlerden vesairelerden gördüklerinden... Hep böyle şey bir algı var ama belli bir kültürel seviyeyi geçmiş insanlarla yaptığınız sohbetlerde... Onlar da bir takım şeyleri gözlemledikleri için, "Ya nasıl işte? Zorluklarını görüyor musunuz?" diyorlar (Istihbarat Şefi, 19 Ekim 2017).

Gazeteciler, toplum nezdinde simgesel sermayelerini görece sürdürse de, haber kaynakları ile ilişkilerde bu sermaye bir hayli aşınmıştır. Özellikle yerel medya bağlamında, gazete çıkarmanın bir "geçim kapısı" olarak sömürülmesi, gazete sahiplerinin kimi zaman gazeteciliği farklı amaçlar için araçsallaştırması, gazeteci kimliğinin itibarını zedeleyen sonuçlara neden olmaktadır:

G: Mesleğe yönelik tavır ve tutumlar nasıl?

Valla vatandaş tabii... Ne diyeyim?.. Sokaktaki vatandaş, "Oo! Gazeteci misin?" falan yapıyor. Çünkü gazeteciler onların gözünde hâla işte televizyonda gördükleri, işte altlarında böyle süper arabalar, böyle inanılmaz olanaklara çalışan kişiler olarak... İşte gerçeğin peşinde koşan, bu yüzden başları beladan kurtulmayan kişiler olarak görüyor. Fakat haber kaynakları için aynı şeyi söyleyemeyeceğim. Özellikle reklam veren haber kaynakları için. Onlar muhtemelen bizi böcek gibi görüyorlardır. Onların gözünde gazeteci, işte parayla satın alınabilecek, açlar ordusu falan... Yani öyle diyebilirim. Bir iki tane de İstanbul'dan da birileri bir örnek anlatmıştı. Bir dondurma şirketi galiba bir organizasyon yapıyor. Şimdi özellikle yemekli organizasyonlara katılım, çok şey olur... Iş̧te kahvaltılı basın toplantıları, akşam yemekli organizasyonlar... Genelde katılım çok yüksek olur... Ve işte bu dondurma şirketi yine dediğim gibi, herhalde böyle bir gündüz toplantı düzenliyor, gelenlere dondurma ikram ediyor vs. Bana anlatanın söylediğine göre, dondurma reyonu yerle bir edilmiş. Çok utanç verici manzaralar ortaya çıkmış (Haber Müdürü, 19 Ekim 2017).

\footnotetext{
İnanamazsınız ya. O insanların varlık içinde düştüğü rezilliğe inanamazsınız. Ne için yapıyorsun bunu? Gazete sahibi geliyor mesela kahvaltıya. Ben tenezzül edip gitmem yani. Ben en baba kahvaltıyı yapsam serpme kahvaltı, 40 lira para. Ve adamın arkasından şunu söylüyorlar: "Kahvaltı var. O yüzden geldi." Adam gazete patronu... Iyi kötü... Ama işte orada ne giriyor artık devreye? Ne zaman öyle oluyor? Hangi aşamadan sonra ona geçiliyor? Onu bilmiyorum (Muhabir, 17 Ekim 2017)
}

Yerel gazeteciliğin idealizm zemininde, zanaata dayalı bir "meslek" olmaktan çok, ilana dayalı bir "iş kolu" na indirgenmiş olması ve kimi gazete sahiplerinin gazeteciliği kolay ve sabit gelir elde edilebilecek bir uğraş olarak görmesi, mesle- 
ğin kültürel ve sembolik sermayesine zarar veren sonuçlara neden olmaktadır. Haber kaynaklarıyla kurulan ilişkilerde temas ve mesafenin önemi düşünüldüğünde, gazetecilerin sermaye niteliklerinin bütünselliği önem kazanır. Kimi zaman gazeteci habitus'u, alanın reel koşullarıyla birleşerek, mesleğin simgesel sermayesini yıkıcı sonuçlara neden olur. Bu durum, alanda eyleyen faillerin sermaye türlerinin, alanın özelliklerini doğrudan etkileme gücünü, alanların otonomisinin önemini ve otonomi eksikliğinin neden olduğu bağıntısal sorunları göstermektedir.

\section{Sonuç ve Değerlendirme}

Bu araştırma, sınırıııkları dahilinde Türkiye'de gazetecilik alt-alanının özelliklerini anlamayı hedeflemiştir. İzmir ölçeğinde ulusal basının bölge ekleri ve yerel gazeteler, ayrım gözetilmeksizin, "yerel"den habercilik pratiğinin örnekleri olarak araştırmaya dahil edilmiştir. Bourdieu sosyolojisinin "alan" kavramsallaştırmasını temel izlek olarak ele alan araştırma, sermaye, strateji, oyun, doxa ve habitus bağlamında analizler içermektedir.

Araştırma sonuçları yerelde habercilik alanının gazeteciler tarafından yüksek düzeyde heteronom algılandığını, heteronominin temel nedenlerinin ise politik etkenler yanında güçlü düzeyde ekonomik bağımlııklar ve gazetelerin sahiplik yapısı olduğunu göstermektedir. Alan, geçmişe göre daralmış, muhabir sayısı radikal biçimde azalmış, ambalaj haberler ve bülten gazeteciliği artmıştır. Alanda ödül-ceza ve liyakat sistemi zayıf olarak tanımlanmakta, "muhabir-bölge temsilcisi" ikiliğinde, meslek içi hiyerarşi ve sermaye dağıımının adaletsizliğinden yakınılmaktadır. "Kurumsal roller, epistemolojik çerçeve ve etik standartlar" üzerine sorgulanmadan kabul edilen fikirler ve ön kabuller bağlamında, doxa zayıftır.

Gazetecilere göre yerelde gazetecilik alanına giriş, yüksek düzeyde sosyal sermaye gerektirmektedir. Kültürel sermaye, merkezde gazetecilik yaparken gerekli görülse de, yerelde inmal edilebilir bir nitelik olarak yorumlanır. Gazetecilik, okur nezdinde simgesel sermayesini görece korusa da, haber kaynakları ile ilişkilerde, bu imaj sorunlu bir hal almaktadır. Gazeteciliğin eski dönemlere kıyasla, ekonomik sermayesi düşük bir mesleğe evrilmesi, alan içi ödül-ceza ve liyakat sisteminin sorunlu işleyişi, gazetecileri özellikle kaynaklar nezdinde daha az saygın, simgesel sermayesi zayıf bir meslek grubu haline getirmiştir. Yetenek, uzmanlık ve bilgide cisimleşen kültürel sermayeye verilen önemin azlığı, alanın otonomisini ve gücünü azaltan önemli bir nedendir. Kültürel sermayenin cisimleştiği en önemli unsurlardan biri olan kurumlara yönelik eleştiriler düşünüldüğünde, gazetecilerin aslında dolaylı olarak, kurumlarda cisimleşen kültürel sermayenin zayıflı̆̆ından yakındığı görülmektedir.

Yerelde habercilik yapan gazetecilerde, güçlü bir merkez-çevre algısı hakimdir. İstanbul ekonomi, Ankara ise bürokrasi gazeteciliğinin, dolayısıyla haberin merkezidir. Özellikle alana yeni girenlerde "Gerçek gazetecilik yapmak için taşradan çıkılmalı, İstanbul'a gidilmeli" algısı hakimdir. Bu bağlamda alan, 
alt-alanı domine etmektedir. Gazeteciler, yerel basının gücüne ve önemine öncelikle kendileri inanmamaktadır. Okur desteğinin zayıflığı ve gazetelerin etkisizliği, bu motivasyonsuzluğu güçlendirmektedir.

Alanda otonomi eksikliği ve ekonomik ve simgesel sermayenin gittikçe zayıflaması, gazetecilerin, ağırlıklı olarak kopma ve kaçış stratejileri geliştirmelerine neden olmaktadır. Bourdieu kavramsallaştırması düşünüldüğünde, alandaki işleyişi ve sermaye dağılımını yıkma eğiliminde olması beklenecek gençler dahi, farklı mesleklere yönelmeyi düşünmekte, alandan tamamen çıkma stratejileri geliştirmektedirler. Yerelde gazetecilik alt-alanı kendine özgü kuralları, karşıtlık ve antagonizmaların varlığı ve görece özerklik düzeyi ile hala bir alan niteliğini korusa da, alanın failleri yüksek heteronomi ve sermaye dağılımının niteliği nedeniyle, illusio'yu her geçen gün yitirmektedirler. Alanda oydaşmaya dayalı, muhakkak addedilen, genelgeçer sayılan bilgi (doxa) eleştirel bir tavırla değerlendirilmekte, ancak bu tavır onun oluşturduğu sembolik iktidarı yıkmaya yönelik stratejilerin önünü açmamaktadır.

Bourdieu, alanlar içinde tahakküm ilişkilerinin, simgesel şiddet aracılığıyla işlediğini belirtmişti. İnsanlar, kendilerinden önce kurulmuş sosyal dünyanın bilgisini muhakkak addetmektedir (taken for granted knowledge). Eyleyiciler dünyayı sorgulamadan benimseyerek, olduğu gibi kabul ederek, mümkün olan en basit şekilde ifade edersek, kendi suç ortaklıklarıyla kendilerine yönelen şiddeti yaratmaktadır (bkz. Bourdieu ve Wacquant, 2016,s .166). Araştırmada gazetecilerin doxayı ve simgesel şiddeti içselleştirmekten çok, onu teşhis ettikleri, nedenlerini tartıştıkları ve alan içi iktidar ilişkilerini netlikle çözümledikleri gözlemlenmiştir. Ancak bu tutum, yıkma stratejilerinden çok alandan çıkış/kopma ve koruma stratejileri ile ikame edilmektedir.

Son olarak, araştırma bulguları düşünüldügünde, şu sonuca varmak mümkün gözükmektedir: yerel gazeteciliği bir alt-alan olarak güçlendirmek, alanın genelini tehdit eden sorunları düşünmeyi gerektirmektedir. Alanın otonomi düzeyini yükseltmenin çarelerini aramak, alana giriş şartlarının aşırı esnekliği ve liyakat eksikliklerini de içeren sermaye türleri üzerine düşünmek, alanı otonom kılacak farklı iş modelleri ya da fonlama stratejilerini tartışmak, kültürel sermayenin ön koşulu olan iletişim eğitiminin niteliklerini gözden geçirmek ve tüm bu çabaya çatı olacak meslek örgütleri ve iletişim fakülteleri üzerine düşünmek, çabanın başlangıcını oluşturabilir. Ancak unutulmaması gereken en önemli unsur, "alanların bağıntısallığı"; dolayısıyla gazetecilik alanının da temelde kültürel üretim, ekonomi ve hepsinden öte -ülkemiz özelinde düşündüğümüzde- politika alanı ile olan zorunlu bağıdır. Politika alanının iktidar ve tahakküm stratejileri, diğer alanların işleyişini ve otonomi düzeyini, doğrudan ve çoğu zaman olumsuz yönde etkilemektedir. Dolayısıyla gazeteciliğin bir alan ve alt-alan olarak otonomiye dayalı inşası, kendi içsel ve tarihsel sorunlarının çözümü yanında, politika alanının demokratik ve hukuksal bir zeminde yeniden inşasıyla doğrudan bağlantııdır. 


\section{Referanslar}

Bourdieu P, (1977). Outline of a Theory of Practice. Cambridge University Press: Cambridge.

Bourdieu, P. (1985). The Social Space and the Genesis of Groups. Theory and Society, 14 (6), 723-744.

Bourdieu, P. (1986). The Forms of Capital. J.Richardson (Ed.), Handbook of Theory and Research for the Sociology of Education içinde. (241-258). Westport, CT: Greenwood.

Bourdieu, P. (1989). Social Space and Symbolic Power. Sociological Theory. 7(1), 14-25.

Bourdieu, P. (1990). In Other Words: Essays towards a Reflexive Sociology. Stanford: Stanford University Press.

Bourdieu, P. (2014). Seçilmiş Metinler. Çev: Levent Ünsaldı, Ankara: Heretik .

Bourdieu, P. (2015). Pratik Nedenler. Çev: Hülya Uğur Tanrı̈̈ver, İstanbul: Hil.

Bourdieu, P. Wacquant, L. (2016). Düşünümsel Bir Antropoloji İçin Cevaplar. Çev: Nazlı Ökten, İstanbul: İletişim.

Bourdieu, P. (2016). Sosyoloji Meseleleri. Çev: Filiz Öztürk, Büşra Uçar, Mustafa Gültekin, Aslı Sümer, Ankara: Heretik.

Calhoun, C. (2016). Bourdieu Sosyolojisinin Ana Hatları. G.Çeğin, E.Göker, A.ArII, Ü.Tatlıcan (Ed), Ocak ve Zanaat: Pierre Bourdieu Derlemesi içinde (77-131). İstanbul: Iletişim.

Deer, C. (2008). "Doxa”. Michael Grenfell (Ed.) Pierre Bourdieu: Key Concepts içinde. Buckinghamshire: Acumen.

Durna, Tezcan. (2016). Türkiye'de Gazeteciliği Bir "Alan" Olarak Yeniden Düşünmek, Ö.Arun, B. Özçetin (Ed.), III Pierre Bourdieu Sempozyumu, Sempozyum Özet Kitabı içinde,file:///C:/Users/G\%C3\%B6k\%C3\%A7en\%20Ba\%C5\%9Faran\%20 \%C4\%BOnce/Downloads/ArunOzcetin_PBSOzetKitab\%20(2).pdf, erişim tarihi: 30.09.2018.

Gezgin, S. (2007). Türkiye'de Yerel Basın. İstanbul: İstanbul Üniversitesi İletişim Fakültesi Yayınları.

Grenfell, M. (Ed.) (2008). Introduction. Pierre Bourdieu: Key Concepts içinde. Buckinghamshire: Acumen.

Jourdain, A. ve Sidonie, N. (2016). Pierre Bourdieu'nün Kuramı ve Sosyolojik Kullanımları. Çev: Öykü Elitez, İstanbul: Iletişim.

Kaya, A. (2016). Pierre Bourdieu'nün Pratik Kuramının Kilidi. G.Çeğin, E.Göker, A.Arlı, Ü.Tatlıcan (Ed.), Ocak ve Zanaat: Pierre Bourdieu Derlemesi içinde (397421). İstanbul: İletişim. 
Maton, K. (2008). "Habitus". Michael Grenfell (Ed.) Pierre Bourdieu: Key Concepts içinde. Buckinghamshire: Acumen.

Stringer, P. (2018). Finding a Place in the Journalistic Field, Journalism Studies, 19 (13), 1991-2000, DOI: 10.1080/1461670X.2018.1496027.

Suminar, P. (2013). Bringing in Bourdieu's Theory of Practice: Understanding Community-Based Damar Agroforest Management in Pesisir Krui, West Lampung District. International Journal of Humanities and Social Sciences , 3(6), 201213. 
